\title{
Histone deacetylase inhibitors: potential targets responsible for their anti-cancer effect
}

\author{
Michael Dickinson • Ricky W. Johnstone • \\ H. Miles Prince
}

Received: 10 November 2010 / Accepted: 12 November 2010/Published online: 14 December 2010

(C) The Author(s) 2010. This article is published with open access at Springerlink.com

\begin{abstract}
Summary The histone deacetylase inhibitors (HDACi) have demonstrated anticancer efficacy across a range of malignancies, most impressively in the hematological cancers. It is uncertain whether this clinical efficacy is attributable predominantly to their ability to induce apoptosis and differentiation in the cancer cell, or to their ability to prime the cell to other pro-death stimuli such as those from the immune system. HDACi-induced apoptosis occurs through altered expression of genes encoding proteins in both intrinsic and extrinsic apoptotic pathways; through effects on the proteasome/aggresome systems; through the production of reactive oxygen species, possibly by directly inducing DNA damage; and through alterations in the tumor microenvironment. In addition HDACi increase the immunogenicity of tumor cells and modulate cytokine signaling and potentially T-cell polarization in ways that may contribute the anti-cancer effect in vivo. Here, we provide an overview of current thinking on the mechanisms of HDACi activity, with attention given to the hematological malignancies as well as scientific observations arising from the clinical trials. We also focus on the immune effects of these agents.
\end{abstract}

Keywords Histone deacetylase inhibitor.

Mechanism of action

\author{
M. Dickinson $(\varangle) \cdot$ R. W. Johnstone $\cdot$ H. M. Prince \\ Department of Haematology, Peter MacCallum Cancer Centre, \\ St Andrew's Place, \\ East Melbourne, VIC 3002, Australia \\ e-mail: mikejd@bigpond.com \\ H. M. Prince \\ e-mail: miles.prince@petermac.org
}

M. Dickinson · R. W. Johnstone $\cdot$ H. M. Prince

University of Melbourne,

Melbourne, Australia

\section{Introduction}

Histone deacetylase inhibitors (HDACi) induce a plethora of molecular and extracellular effects that singly, or in combination, result in potent anti-cancer activities. The clinical development of HDACi has been rapid, but fundamental questions about the mechanisms of anticancer activity remain: which $\mathrm{HDAC}(\mathrm{s})$ must be targeted to mediate the observed anticancer effects? Which molecular processes (ie chromatin remodeling, regulation of transcription factors, acetylation of non-histone targets) are critical? Finally, is apoptosis, differentiation or another biological effect responsible for the clinical responses we see? While it is clear that HDACi induce apoptosis associated with altered transcription of proteins involved in the intrinsic and extrinsic pathways, other mechanisms are in play, such as those relating to the aggresome/proteasome system. Through hyperacetylation of histone and non-histone targets, HDACi can induce quite diverse cellular effects. These include: altering immune responses through effects on the host and/or target cells; inducing permanent (i.e. senescence) or temporary (quiescence) cell cycle arrest usually at the G1/S transition; inhibiting angiogenesis; inhibiting apoptosis; and autophagy [1-5]. HDACi not only induce injury to the cell, they also modulate its ability to respond to stressful stimuli. Moreover, the anti-tumor effect is due to targeting not only the tumor cell itself, but also the tumor microenvironment and the immune milieu.

\section{Inhibition of histone deacetylases and classification of the HDACi}

HDACs are classified by their homology to yeast HDACs. Eighteen are known, of which the 11 zinc-dependent 
enzymes belonging to class I, II, and IV constitute the focus of research, and of this review. HDACs, usually in conjunction with other corepressors, deacetylate lysine moieties in amino-termini of histones [6]. The acetylation status of the histone depends on the balance between deacetylase activity and histone acetyl transferase (HAT) activity. Deacetylation results in a relatively closed chromatin conformation that often leads to repressed transcription [6]. Thus, HDAC inhibitors are generally considered to be transcriptional activators [7]. However, gene expression profiling shows that as many genes may be repressed as derepressed after exposure to an HDACi. This is likely to be a consequence of the direct and indirect effects of these drugs on other transcriptional regulators and cell signaling pathways and/or due to the dynamic and complex interrelations between chromatin remodeling and regulated gene transcription $[8,9]$.

HDACi are currently classified according to their chemical structure, and each agent varies in its ability to inhibit individual HDACs (Table 1). HDACi share a common pharmacophore containing a cap, connecting unit, linker and a zinc binding group that chelates the cation in the catalytic domain of the target HDAC [10]. The pandeacetylase inhibitors include vorinostat (suberoylanlide hydroxamic acid, SAHA), panobinostat (LBH589) and trichostatin A which inhibit class I, II and IV HDACs, while valproate, entinostat (MS-275) and romidepsin (depsipeptide, FK228) are considered class-I-specific, and tubacin, HDAC6-specific. (Table 1)

HDAC6 warrants special attention as a HDAC predominantly, [11, 12] but not exclusively [9] localized to the cytoplasm. HDAC6-specific effects, particularly those on cell motility and the proteasome and aggresome pathways (discussed below) are considered by some investigators to be responsible for much of the cytotoxicity of the HDACi. This is one example of how HDACi vary in their targetsthe pan-HDACi include HDAC6 amongst their targets, while the class 1-selective HDACi (such as romidepsin) do not. Such differences provide the rationale for the development of novel, highly HDAC-specific agents. For now, it is easiest to group the HDACi in commercial development into the pan-HDACi versus those that are class 1-specific, and it is probably not unreasonable to make generalizations about HDACi targets on that basis.

\section{Apoptosis}

HDACi can induce high rates of apoptosis at sub-micromolar concentrations in many cell-line models of hematological malignancy. Precisely which of the effects discussed below is most important remains a matter of conjecture and may well be cell-type and agent-specific. The two major apoptotic pathways are the death receptor (direct) and mitochondrial (indirect) pathways. HDACi have been shown to induce apoptosis through effects on mediators within either pathway or by inducing other signals within other cellular pathways that activate apoptosis.

Death receptor pathway

The death receptor pathway is triggered by the ligation of death receptors (Fas, TNF-R1, TRAIL) on the cell surface by tumor necrosis factor (TNF)-super family receptor ligands (Fas-L, TNF $\alpha$, TRAIL, TR1a). In the case of TRAIL-induced death though ligation DR4 /TRAIL-R1 or DR5/TRAIL-R2, the adaptor molecule FADD is recruited, leading to caspase 8 activation through formation of the multi-protein death inducing signaling complex (DISC) and activation of final common effector, caspase 3. CFLIP may inhibit or potentiate the binding of FADD and caspase 8 , but is generally seen as an inhibitor of apoptosis $[13,14]$. Tumor cells are more sensitive to TRAIL-induced death than normal cells, [15] and HDACi may further sensitize malignant cells to death-receptormediated apoptosis.

HDACi can increase expression of death receptors DR5 expression can be induced by HDACi in a dose and timedependent manner in AML (HL-60), CML (K-562) [16] and myeloma cell lines [17]. Similarly, in mouse models of acute promyelocytic leukemia (APL) and AML-ETO dependent leukemia, valproic acid increased expression of death receptors and their ligands by the leukemic cells and cell death was dependent on the death-receptor pathway. These observations were confirmed in primary APL and AML-ETO samples, and were not seen on CD34+ stem cells from the same patients [18].

HDACi can induce apoptosis by directly stimulating the death receptor pathway Increased susceptibility to TRAILmediated death may occur without altered receptor expression. HDACi were able to re-sensitize Jurkat T-cell leukemia cells with acquired resistance to TRAILmediated death without changes in surface expression of death receptors, suggesting that in these cells post-DISC changes to the apoptotic cascade was important [19]. CLL cells are typically resistant to TRAIL-mediated death, [20] yet romidepsin and sodium valproate can sensitize CLL cells to DR4-mediated death through increased recruitment of FADD to the DISC [21-23].

TRAIL/Fas sensitization may also occur through downregulation of c-FLIP [24-29] or increased expression of APAF1 [30]. These observations have been replicated in a mouse model where vorinostat augmented the effects of a murine DR5 agonist through down-regulation of c-FLIP 
Table 1 Classes of DAC inhibitors, their HDAC targets and HDAC cellular distribution

\begin{tabular}{|c|c|c|c|c|c|c|c|c|c|c|c|c|}
\hline \multirow[b]{4}{*}{ HDACi Class } & & \multicolumn{11}{|c|}{ HDAC specificity } \\
\hline & \multirow{2}{*}{$\begin{array}{r}\text { HDAC Cellular distribution } \\
\text { HDAC Class }\end{array}$} & \multicolumn{4}{|c|}{ Nuclear } & \multicolumn{4}{|c|}{ Nuclear, Cytoplasmic } & \multicolumn{2}{|c|}{ Cytoplasmic $^{a}$} & \multirow{2}{*}{$\begin{array}{c}\text { Nuclear } \\
\text { IV }\end{array}$} \\
\hline & & & & & \multirow[b]{2}{*}{8} & \multicolumn{4}{|c|}{$\| l a$} & \multicolumn{2}{|c|}{$11 b$} & \\
\hline & $H D A C$ & 1 & 2 & 3 & & 4 & 5 & 7 & 9 & 6 & 10 & 11 \\
\hline \multirow[t]{2}{*}{ Short chain fatty acids } & Butyrate & & & & & & & & & & & \\
\hline & Valproate & & & & & & & & & & & \\
\hline \multirow[t]{6}{*}{ Hydroxamic acid derivative } & Trichostatin A & & & & & & & & & & & \\
\hline & Vorinostat (suberoylanilide & & & & & & & & & & & \\
\hline & hydroxamic acid, SAHA) & & & & & & & & & & & \\
\hline & Panobinostat (LBH589) & & & & & & & & & & & \\
\hline & Belinostat (PXD101) & & & & & & & & & & & \\
\hline & Tubacin & & & & & & & & & & & \\
\hline \multirow[t]{2}{*}{ Benzamide } & Entinostat (MS-275) & & & & & & & & & & & \\
\hline & Mocetinostat (MGCD0103) & & & & & & & & & & & \\
\hline Cyclic tetrapeptide & Romidepsin (depsipeptide) & & & & & & & & & & & \\
\hline
\end{tabular}

${ }^{a}$ HDACs 6 \& 10 are typically found in the cytoplasm [12] however both have also been found in the nucleus and are likely to affect transcription [9, 220].

and XIAP and without changes in the expression of the receptor or of TRAIL [31].

Moreover, synergy of HDACi with death receptor agonists, in vitro and in vivo, has been demonstrated with different putative and possibly cell-line-dependent mechanisms $[15,17,24,31]$.

Death receptor signaling may not be essential for $H D A C i$ induced apoptosis Recent evidence shows that death receptor signaling is not essential for HDACi-induced apoptosis in various experimental model systems. Panobinostat and the related pan-HDACi LAQ824 were able to induce apoptosis and have a therapeutic effect in a transgenic murine model of Burkitt lymphoma $(\mathrm{E} \mu-m y c)$ $[32,33]$. This effect was preserved in an E $\mu-m y c /$ TRAIL $^{-/}$ murine model in which TRAIL was not expressed.

Intrinsic (mitochondrial, stress-activated) pathway

The intrinsic pathway is activated by cell stress stimuli, such as free-radical generation, the generation of misfolded proteins, chemotherapy, and radiation or DNA damage. The increased mitochondrial permeability that ensues through activation of Bax and Bak results in the release of proapoptotic proteins, which in turn activate caspase 9 and finally, the common effector caspase, caspase 3. This pathway is partly controlled by the interplay between proapoptotic multidomain BCL-2-family proteins which may initiate mitochondrial membrane permeability (Bax and Bak), the pro-apoptotic BH3-only proteins (Bad, Bik, Bid,
Bim, Bmf, Hrk, Puma, Noxa) that act as "sensors" of cellular stress and activate the intrinsic apoptotic pathway and pro-survival BCL-2-family proteins (BCL-2, BCL-XL, BCL-W, MCL-1, A1) that serve to "protect" mitochondrial integrity. There is interconnection between the extrinsic and intrinsic pathways through activation of Bid following cleavage by caspase-8 [34]. HDACi modify the cell's ability to respond to stressors, favoring apoptosis, and in addition probably contribute directly to cellular stress.

Gene expression profile studies show that HDACi alter the expression of members of the intrinsic apoptosis cascade such that the overall profile is pro-apoptotic [15, 17, 35-40]. For example, BCL-XL and BCL2 are often down regulated, and Bim, Bax and Bak are consistently up regulated [35, 40-43].

Over expression of BCL-2 or BCL-XL appears to be an important mechanism of resistance to HDACi, which can be overcome with small molecule inhibitors of BCL-2 such as ABT-737 [27, 30, 32, 33, 44-49]. Exploratory gene expression profile studies on clinical samples from patients with cutaneous $\mathrm{T}$ cell lymphoma (CTCL) treated with the HDACi panobinostat showed altered expression of $\mathrm{Bcl} 2$ family genes [50]. However, whether these are direct effects of the altered histone structure or associated with alterations in other mediators of transcription remains unclear.

The absence of a functional apoptosome does not preclude a efficacy from the HDACi. In an E $\mu$-myc mouse model in which either apaf-1 or caspase 9 were deleted, apoptosis was reduced, however HDACi were still able to kill the tumour cells and doubled the survival of the mice affected by this aggressive model of lymphoma [33]. 
Accumulation of reactive oxygen species (ROS) occurs after exposure to HDACi, and may trigger apoptosis selectively in cancer cells [51-56]. Normal cells appear to be spared of this effect, possibly through up regulation of the Trx-binding protein -2 , which protects cells from the effects of ROS in normal but not tumor cells [51, 57]. The relative importance of ROS to HDACi induced apoptosis is suggested by the ability of the PEITC (a glutathione depleting compound) to enhance the cytotoxicity of vorinostat in leukemia cell lines and primary samples [56].

\section{The ubiquitin/proteasome system and the misfolded protein response}

Another potential trigger of HDACi-induced cell death arises through the potential effect of these agents on the misfolded protein response (MPR). The MPR is comprised of a number of cellular processes which protect the cell from toxicity arising from the accumulation of misfolded proteins. Misfolded proteins may arise as a consequence of defective protein synthesis, or due to other cellular derangements that result in a change in conformation of pre-formed protein [58]. Folding of proteins occurs in the endoplasmic reticulum (ER) and is reliant on the chaperone function of HSP90 [59, 60]. In this way, HSP90 prevents degradation of client proteins.

The ER responds to increased transcriptional activity in the cell by activation of the ER stress response. Through signaling from the ER three responses to increased ER stress can be initiated: 1. Decreased protein transcription, 2. Increased transcription of genes of the ER to increased long term processing capacity, or 3. apoptosis [60]. Apoptosis may be initiated by a number of trans-membrane receptors in the ER that then activate the intrinsic apoptotic pathway via c-Jun terminal kinase (JNK) [61]. Misfolded proteins may also be targeted for destruction through the proteasome. Targeting to the proteasome occurs through a number of protein modifications most importantly, ubiquitinylation.

Aggregates of misfolded protein are relatively resistant to destruction by the proteasome, and form in the context of proteasome inhibition, insufficiency or dysfunction [62]. Misfolded proteins accumulate focally in into an aggresome via a microtubule-an HDAC-6-dependent mechanism. The aggresome is then targeted for destruction by the autophagosome [12, 62-64]. Overall, the aggresome pathway is a homeostatic and cytoprotective mechanism which may rescue the cell in the context of proteosomal overload, inhibition or dysfunction. The ubiquitin-proteasomeaggresome pathways are thought to be particularly relevant targets for anti-cancer therapy of myeloma, where production of immunoglobulin requires a properly functioning endoplasmic reticulum and proteasome.
HDAC inhibitors affect functioning of the proteasome / aggresome pathways in three key ways (which make their combination with proteasome inhibitors particularly appealing) [65]. Firstly, inhibition HDAC6 results in hyperacetylation of HSP90 and HSP70 [66] which subsequently promotes misfolding and depletion of client proteins, including c-RAF, AKT and CDK4 and induces ER stress [67-70]. Recent evidence suggests that in a model of mantle cell lymphoma, induction of the ER stress-response gene CHOP is critical to panobinostat-induced cytotoxcity [68]. Secondly, HDAC hyperacetylation of tubulin leads to defective function of the dynein motor complex required for aggresome formation [7, 62, 63, 65, 68]. Inability to compensate for additional ER stress through a functioning aggresome pathway primes the cell for, and potentially initiates, apoptosis. Finally, a loss of function screen, discovered that proteasome deregulation through a pathway involving HR23B (RAD23B) was in part responsible for HDACi-induced apoptosis [72]. HR23B possesses ubiquitin-like domains and shuttles proteins to the proteasome. It also has a role in nucleotide excision repair, which was not shown to be critical in the effects of the HDACi. In this study, CTCL cells possessing higher levels of HR23B were more sensitive to HDACi induced death, and HDACi were shown to decrease proteasome function in treated cells in an indirect manner. Experimental depletion of the HR23B restored proteasomal function and reduced HDACi sensitivity. These observations were expanded in a subsequent study [73] in which an association between reduced HR23B expression in CTCL tissue biopsies and clinical response was observed. The authors concluded that HR23B expression may prove to be a useful biomarker to predict responsiveness to $\mathrm{HDACi}$.

The evidence pointing to aggresome and proteasome dysfunction after HDACi therapy and the importance of HDAC6 in the maintenance of ubiquitin-proteasomeaggresome function [74] has been the basis for combinations of HDACi with proteasome inhibitors [71, 75]. However HDAC6 inhibition and tubulin acetylation may not be required, either for $\mathrm{HDACi}$ efficacy as a mono therapy or for synergy from the combination of $\mathrm{HDACi}$ with the proteasome inhibitors [76]. Buglio et al, hypothesized that the HDAC-selective mocetinostat (which has no effect on HDAC6) would make a more attractive agent for combination with bortezomib due to a perceived lower risk of thrombocytopenia compared to the pan-HDACi. Their preclinical experiments showed that the combination of mocetinostat and bortezomib was synergistic in Hodgkin lymphoma cell lines through reduction of the $\mathrm{NfKb}$ levels typically associated with HDAC inhibition. This synergy was HDAC6-independent, and brings into question the necessity for HDAC6 inhibition for combination therapies with the proteasome inhibitors. In a recent clinical study, 
the combination of bortezomib with the HDAC 1 and 2specific romidepsin was able to rescue patients with bortezomib-refractory myeloma, adding weight to the concept that inhibition of HDAC6 is not required for this type of drug combination to be of benefit to patients [77]. Indeed, although not compared directly in a trial, romidepsin appears to be at least as effective as the pan-HDACi, vorinostat for cutaneous T-cell lymphoma, the only indication for which HDACi have earned FDA approval [78].

\section{Changes to p53 and the cell cycle}

p53 is one of the most commonly altered transcription factors in cancer, and is found to be inactivated or mutated in various acute leukemias, CLL, myeloma and lymphoma. It is a promiscuous transcription factor with interactions with many key cellular pathways, including, but not limited to, those of Rb-E2F, MAP-kinase, IGF-1/AKT, Wnt-betacatenin and cyclin-CDK via p21 [79]. Wild-type p53 is activated and accumulates in the nucleus in response to stress signals such as DNA damage, hypoxia, spindle damage and heat shock, amongst others. This response is modified by kinases (ATM, AT, CHK2, CHK1), acetyltransferases (CBP/ p300, pCAF, TRAF), PML, SUMO-1 and HMG1 and also deacetylases including the HDAC1/ mSin3 complex [79-85]. Ubiquitin-mediated proteasomal degradation contributes to the control of p53 levels. The overall effect of p53 activation is cell cycle arrest (predominantly by activation of $\mathrm{p} 21^{\mathrm{Wafl} / \mathrm{Cip} 1}$ ) and apoptosis (through increased expression of pro-apoptotic genes of the intrinsic pathway).

Many of the pathways discussed in this review influence p53, and thus the HDACi have several means of modulating p53. The importance of the acetylation status of p53 (and thus the role of direct HDAC-p53 interactions) is controversial [86], however there is evidence that acetylation of p53 is enhanced in the setting of cellular stress [81], is required to interrupt Mdm-2 mediated repression of $\mathrm{p} 53$, $[84,87]$ increases the affinity of p53 for DNA [88], reduces ubiquitin-mediated degradation of the transcription factor [89], and can enhance expression of $\mathrm{p}^{2} 1^{\mathrm{Wafl} / \mathrm{Cip} 1}$ [89]. A number of studies demonstrate activation of p53 after HDAC inhibition [89, 90]. However in most reports the apoptosis and p21 induction following HDAC inhibition can be induced in a p53 independent manner - an observation that may be clinically relevant for the treatment of tumors harboring mutated p53 [32, 48, 91-93].

It is postulated that the HDACi-mediated effects on the cell cycle may be a key reason for the differential toxicity and responses between normal and transformed cells. Cell cycle arrest at G1 associated with induction of CDKN1A/ $\mathrm{p} 21^{\mathrm{WAF} 1 / \mathrm{CIP} 1}$ is a key response to almost all of the currently available HDACi [1, 7, 94, 95]. Down-regulation of CCND1/cyclin D may also contribute [96, 97]. However, induction of cell cycle arrest may protect cells against cytotoxic agents that require cell cycling for efficacy. Cell cycle arrest may also partly explain the tumor selectivity of HDACi $[98,99]$. HDACi can also induce cell cycle arrest at G2/M. Tumor cells lacking a functional G2 checkpoint and that proceed into mitosis after HDACi therapy, undergo apoptosis. By contrast, normal cells (with an intact G2 checkpoint) are able to maintain arrest G2/M following withdrawal of HDACi treatment [98, 99]. This difference may go some way towards explaining the tumor selectivity of the HDACi.

\section{Cytokine signaling}

Hematological malignancies are frequently associated with altered cytokine dependency, with perturbation of cytokine expression, receptor abnormalities, or with dysfunction of the post-receptor signaling cascades. Generally, binding of a cytokine to its receptor results in receptor dimerization. The cytoplasmic domains of cytokine receptors bind JAKs (Janus kinases) which phosphorylate the receptor and activate each other. In turn, the signal transducer and activators of transcription (STATs) are activated, also by phosphorylation, and STAT dimers enter the nucleus to initiate transcription at specific promoter regions. Chromatin remodeling is required for maximal transcriptional effect, and this is achieved through recruitment of HATs, $[100,101]$ as well as HDACs [102-105].

Activation of the STAT3 signaling pathway is associated with multiple cellular effects including increased proliferation and cell survival (through induction of pro-survival Bcl-2 family members), induction of angiogenesis, inhibition of $\mathrm{p} 53$, and with activation of Rel/NFk $\beta$ [106]. STAT3 hyper activation is described in multiple myeloma (where IL-6 dependence is of particular significance), [107-109] Hodgkin lymphoma, [110-114] c-myc dependent lymphoma, [115] diffuse large B cell lymphoma, [116] and the Tcell lymphomas [42, 106]. Mycosis fungoides and Sézary syndrome are associated with constitutive activation of STAT3 and probably induced over activity of STAT5 [100, $117,118]$. STAT5 hyper activation is also described in Hodgkin lymphoma, $[119,120]$ as is IL-4/STAT6 activation (with production of the cytokine thymus and activationregulated chemokine- TARC) [121-124]. For a review of the role STATs in cancer, the reader is referred to a review by Yu and Jove [125]. The aberrancy of STAT activation in many hematological malignancies makes the STATs a rational target for anticancer agents.

The STATs are among the non-histone proteins hyper acetylated in response to HDACi. In addition to phosphor- 
ylation, STAT1 activity is partially regulated by CBPinduced acetylation or HDAC1-influenced deacetylation [101, 105, 126]. Acetylated STAT1 binds to the RelA subunit of NFK $\beta$ and prevents its nuclear translocation and anti-apoptotic effects [127]. Furthermore, STAT1- and STAT2 - mediated transcription of genes is reduced after HDAC inhibition [86, 102, 103, 128, 129]. HDAC inhibition prevents the transcription of the targets of STAT5, by preventing the recruitment of SMRT, rather than by alterations of histone acetylation [104].

In a murine xenograft model of CTCL, panobinostat reduced levels of (activated) pSTAT3 and pSTAT5 in biopsies, but not the overall quantity of either STAT protein [49]. An early study suggested that STAT6 expression was reduced after treatment with vorinostat in skin lymphoma biopsies without changes to expression to STAT3 [130]. Subsequently, an important study by Fantin and colleagues demonstrated that clinical response to vorinostat was associated with a change in localization of pSTAT3 from predominantly nuclear to predominantly cytoplasmic, presumably reflecting functional inactivation of pSTAT3 by vorinostat in these responding patients. A lack of in vitro and clinical response of CTCL to vorinostat appears to be associated with persistent accumulation of nuclear pSTAT3 [42, 118].

In Hodgkin lymphoma, mocetinostat downregulates the expression of STAT6 and its target cytokines TARC and IL5 , with paradoxical increases in IL-13 [121]. It is postulated that altered cytokine profile results in a shift to a $\mathrm{T}_{\mathrm{H}} 1$-type cellular response to the Reed-Sternberg cell.

Together, these observations suggest that effects on the JAK/STAT pathways and altered cytokine signaling are putatively important therapeutic targets of the HDAC inhibitors that warrant further clarification. Indeed, STATdependency may explain why it is the hematological malignancies that show the most promising responses to these agents.

Impact on the $N F k B$ system $N F \kappa \beta$ is a key transcription factor, sometimes termed the "master regulator", with antiapoptotic effects and control over a number of inflammatory cytokines. When activated, it increases transcription of a number of pro-survival genes in the indirect apoptosis pathway. Constitutive activation of the NFK $\beta$ pathway is a feature of CTCL and myeloma, ALL, NHL (particularly activated B cell subtype of diffuse large cell lymphoma and mantle cell lymphoma) and CLL [131]. The inhibitory protein IKB prevents transcription of $\mathrm{NfKb}$ target genes by preventing entry of NFkB into the nucleus of the cell [132]. During inflammation there is phosphorylation and ubquitinylation of $\mathrm{I} K \mathrm{~B}$, which targets I $\mathrm{KB}$ for destruction by the proteasome. This results in increased translocation of $\mathrm{NfKb}$ to the nucleus with increased gene transcription. Although recently brought into question, $[133,134]$ one important effect of the proteasome inhibitor bortezomib in myeloma is to reduce $\mathrm{NfKb}$ translocation to the nucleus by reducing proteasomal degradation of IkB.

$\mathrm{NfKb}$ is acetylated by $\mathrm{p} 300 / \mathrm{CBP}$, the biological effect of which varies according to the acetylation site. HDACi block HDAC3-mediated deacetylation of the p65/RelA $\mathrm{NfKb}$ subunit, leading to impairment of the $\mathrm{IkB} / \mathrm{cNfKb}$ binding, increased NfKB nuclear translocation and increased DNA gene transcription [135]. Histone deacetylase inhibitors also activate $\mathrm{NFkB}$ via induction of reactive oxygen species (ROS) and the ATM/ NEMO/ SUMOylation pathway as well as the DNA damage response [54]. Activation of NfKB following HDAC inhibition may well be cytoprotective (pro-survival) and an important mediator of HDACi-resistance. As already discussed, this activation of $\mathrm{NfKb}$ may be meaningfully addressed by combining HDACi with proteasome inhibitors [77].

\section{Immuno-modulatory effects of HDACi}

\section{Cellular immunogenicity}

In addition to altering cellular responses to cytokine receptor activation through the pathways discussed above, HDACi appear to modulate multiple arms of the immune system, and are able to also act in a pro- or antiinflammatory manner. Presently it is uncertain if the net effect potentially improves or hinders anti-cancer immune surveillance.

Up regulation of surface molecules Romidepsin, trichostatin A and sodium butyrate were able to up regulate costimulatory (CD80, CD86) and adhesion (ICAM-1) molecules as well as HLA-DR on HL-60 (promyelocytic leukemia) cells, which was associated with an increased mixed leukocyte response when compared to untreated cells [136]. This up regulation, also observed in solid tumors models, [137-140] may reduce the ability of a tumor to escape immune surveillance [141, 142]. Tumor immunogenicity may also be increased through increased expression of tumor-associated antigens. The carcinoma/ testis antigens (CTA) are an attractive target for immunotherapy because they are sparingly expressed in normal, non-testicular tissue $[143,144]$. CTA-specific cytotoxic Tlymphocytes (CTL) are detectable in patients with CTAexpressing tumors, and CTA have become a attractive target for adoptive cellular immunotherapeutic strategies. Previous studies show that expression the MAGE proteins is under epigenetic control and may be altered by the HDACi [145] and DNA demethylating agents [146]. Conceivably, CTA-specific CTL-response can therefore be 
promoted through the use of epigenetic modifiers, which may act to up-regulate the target antigen [147, 148]. CTA are expressed on the Reed-Sternberg cell in approximately a third of untreated cases of Hodgkin Lymphoma [143]. The class-1 isoform-selective HDACi entinostat increased the expression of testicular associated-associated antigens SSX2 and MAGE-A on Hodgkin lymphoma cell lines [149]. Similar observations have been made in myeloma $[148,150]$ and AML [151]. There is now rationale to assess whether the epigenetic modifiers can be used to modulate graft-versus-host/graft-versus-tumor effects [151] or improve adoptive cellular immunotherapeutic strategies.

Effect on NK cells The cytotoxic activity of NK cells is influenced by their engagement with stimulatory or inhibitory signals provided by the tumor target cells. NKG2D is an activating receptor expressed on NK cells, which also has co-stimulatory functions on $\mathrm{CD} 4+$ and $\mathrm{CD} 8+\mathrm{T}$ cells and macrophages. MICA, MICB and ULBP are among the stimulatory ligands for this receptor, which promote NKcell mediated killing of tumor cells [152]. These ligands are expressed in response to cellular stress [153] Up regulation of NGK2D ligands solid tumor and AML cells with increased NK-mediated cell killing has been demonstrated after treatment by HDAC inhibitors [154-157]. In a CMLcell line, this affect was accentuated by treatment with hydroxyurea, presumably by accentuation of the DNA damage response $[152,158,159]$. These observations are tantalizing given the role of other NK-stimulatory agents in the management of hematological malignancies such as myeloma and MDS, and the potential for combination strategies $[160,161]$.

Effect on antigen-presenting cells HDACi appear to reduce differentiation and maturation of monocyte-derived human dendritic cells (DC), as well as reduce antigen uptake and antigen-specific immune responses after stimulation with Toll-like receptor (TLR) ligands [162, 163]. This effect was also seen in DCs in a murine model of graft versus host disease (GVHD), and in both contexts the effects were associated with reduced DC production of IL-12, IL-6 and TNF-a, and a reduced mixed leukocyte response (MLR) [164]. The mixed leukocyte response (MLR) to human and mouse-derived DCs treated with HDACi was consistently reduced, and in mice treated with HDACi, GVHD was ameliorated. These observations suggest a role for HDACi as anti-inflammatory agents, but also suggest that they may interfere with vaccine-based anti-cancer interventions (including dendritic cell vaccine therapy).

HDACi affect $T$ cell polarization The changes to STAT signaling and cytokines described above and which are strikingly demonstrated in the setting of Hodgkin lympho- ma, would be expected to shift the cellular immune response from a $\mathrm{T}_{\mathrm{H}}-2$ (IL-5/ IL-4 / IL-13 driven) to a $\mathrm{T}_{\mathrm{H}} 1$ response [123]. Given the significant contribution of deranged cytokine signaling in HL, [165] and of the nonmalignant cellular milieu responsible for much of the bulk of Hodgkin Lymphoma tumors, there is a real possibility that this hypothesized shift in T-cell polarization contributes to the observed clinical response [166].

$T$ regulatory cells Generally, an increase in the number of $\mathrm{T}_{\text {regs }}$ is considered to be immune-suppressive and to impair anti-cancer immune surveillance [167-171]. The significance of increased $T_{\text {reg }}$ numbers in the marrow of patients with marrow involvement is unknown, but in solid tumors $\mathrm{T}_{\text {reg }}$ assist in tumor immune-escape [172]. $\mathrm{T}_{\text {reg }}$ numbers are high in lymph nodes containing follicular lymphoma, but surprisingly portend an improved prognosis and chemotherapy sensitivity. By contrast elevated $T_{\text {regs }}$ confer a poorer prognosis in AML. Reduced $\mathrm{T}_{\text {reg }}$ numbers are associated with clinical responses to the immunemodifying agents thalidomide and lenalidomide in myeloma and CLL. Notably, the transcription factor Foxp3 (which is uniformly expressed in $T_{\text {reg }}$ ) is under epigenetic control, [173] is stabilized by acetylation and is upregulated after HDACi therapy [174]. While HDACi appear to increase $T_{\text {reg }}$ numbers and function in mice, $[167,174]$ whether that occurs in humans in the setting of cancer is unknown.

Manipulation of this immune response provides some rationale for the use of HDACi to establish immune tolerance in GVHD but conversely provide a reason for caution for the use of these agents to augment anti-cancer immune responses [167]. These observations are curious given the FoxP $3+/ T_{\text {reg }}$ phenotype of the HDACi-responsive CTCL, and warrant further exploration in this disease [175].

When considered together, it is clear that there is sufficient evidence to consider HDACi immune modulating agents. Whether the overall effect is important for the anticancer effect, or limited to particular tumor types, remains to be seen.

\section{Tumor microenvironment}

Levels of pro-angiogenic factors such as vascular endothelial growth factor (VEGF), basic fibroblast growth factor (bFGF) and hypoxia-induced factor $1-\alpha(\mathrm{HIF} 1 \alpha)$ are increased in the in a number of hematological malignancies, especially in the bone marrow microenvironment [176]. Targeting tumor angiogenesis has proven to be a valuable strategy in the therapy of solid tumors using VEGF/EGFR 
inhibitors, as well as myeloma and myelodysplasia through the use of immunomodulatory agents (lenalidomide and thalidomide) and for the former, the proteasome inhibitors [176] Hypoxia-inducible factor 1- $\alpha$ (HIF $1 \alpha)$ is considered a master regulator of the cell's response to normoxic and hypoxic conditions. Levels of HIF $1 \alpha$ are modulated through ubiquitination and proteasomal degradation, with complex interactions between p300/CBP, pVHL and HDACs 1,3, 4, 6, and 7 influencing this process (see review by Ellis et al.) [177]. Increased levels of these HDACs appear promote angiogenesis, conversely HDAC5 appears to be an inhibitor of angiogenesis [178].

HDACi have been shown to suppress angiogenesis in a number of cell types across a range of experimental conditions [177, 179-186]. Down regulation of genes associated with angiogenesis (GUCY1A3, ANGPT1, COUP-TFII) has been documented in clinical CTCL samples after treatment with panobinostat [50] and TSP1 after treatment with vorinostat [118]. Similarly, reduction in VEGF, sVEGFR1, and bFGF were seen in samples from patients with myeloma who had been treated with panobinostat [187] and skin biopsies of cutaneous lymphoma from patients treated with vorinostat show reduced microvessel density [118].

Combination strategies with specific small-molecules inhibitors of angiogenesis are being explored in the solid tumor setting, and should be considered for haematalogical malignancies thought to depend on angiogenesis [181, 182, 188].

\section{Histone deacetylase inhibitors and drug-resistant clones-targeting the cancer stem cell}

Given that tumor-regrowth occurs after clinical remission implies the presence of subpopulation of cancer cells that are relatively resistant to primary treatment [189]. Such resistance may be present in a subset of cells prior to treatment or may develop as a consequence of exposure to drugs, through a process of natural selection. The cancer stem cell hypothesis somewhat controversially proposes that within a cancer there is a phenotypically distinct subpopulation of cells responsible for the clonogenic potential of the tumor [190-195]. The putative cancer stem cells are said to form the minority of overall cancer cell population, have the capacity for self-renewal, and importantly are potentially more resistant to anti-cancer agents. A host of mechanisms of resistance to a variety of anti-cancer treatments have been demonstrated in various putative cancer stem cell models, including hedgehog signaling in multiple myeloma [191, 194, 196], increased drug efflux, and changes in Notch and Wnt signaling in AML, CML and T-ALL. (See reviews by Lin et al. and references therein) $[190,193]$.
Sharma et al. recently demonstrated the ability to detect a subpopulation of PC9 lung cancer cells that were resistant to erlotonib, termed "drug-tolerant persisters" (DTPs) [197]. These DTPs all possessed the putative cancer stem cell marker CD133 that was present on only $2 \%$ of the original, untreated PC9 population. When grown in drugfree media, the cells re-acquired a drug-sensitive phenotype, this 'elasticity' implying an epigenetic mechanism of drug resistance. Supporting this was data from gene expression profiling of the two cell lines (drug-sensitive and drug-resistant) which was consistent with a global epigenetic modification. The authors identified that the retinoblastoma protein and HDAC-demethylating protein KDM5A was unregulated in the DTPs and found that histone $\mathrm{H} 3$ was consistently hypoacetylated in the DTPs. Trichostatin A was lethal to DTPs but not to the drug-sensitive cells, supporting the theory that the drug-resistance state was dependent on global chromatin changes and HDACdependence. Application of four different HDAC inhibitors to PC9 cells prior to exposure to erlotonib and a number of other anti-cancer drugs including cisplatin, prevented the development or expansion of DTPs without effect on the proliferation or survival of the PC9 cells. These observations offer the tantalizing possibility that HDACi can target the putative cancer stem cell or circumvent acquired drug resistance, and clearly offer a direction for further research.

Potential effect on leukemias with recurrent cytogenetic abnormalities

Fusion proteins associated with the acute leukemias interact with HDACs and offer appealing targets for the HDAC inhibitors. Fusion of the retinoic acid receptor- $\alpha$ (RARA) with PML or the PLZF loci results in acute promyelocytic leukaemia. The retinoic acid receptors (RAR) repress transcription through recruitment of corepressors that in turn recruit HDAC1 [198]. Ligation of RAR leads to dissociation of the HDACs and recruitment of HATs, and transcriptional activation [198]. Both fusion proteins require higher concentrations of retinoic acid to achieve the same level of HDAC dissociation. The result, phenotypically, is maturation arrest and proliferation at the promyelocyte stage [198-200]. This effect can be overcome by high concentrations of trichostatin A [199] an observation reciprocated in a mouse model, [201] as well as in patients with all-trans-retinoic-acid resistance [198, 202, 203].

An analogous situation arises with AML1/ETO, the commonest recurrent fusion protein in AML. AML1 is a transcriptional activator and achieves this effect through the recruitment of HATs [198, 204, 205]. The ETO portion of the AML1/ETO fusion instead appears to recruit a corepressor complex containing $\mathrm{HDAC} 1$, histone methyltransferase, DNA methyltransferase as well as meythl-CPG binding properties. 
Transcription is repressed through dysfunction of RARA [206]. HDACi induce apoptosis in AML1/ETO-bearing cells [207, 208] and romidepsin has antileukemic activity (albeit limited) in patients with AML/ETO leukaemia [209].

The MLL locus on chromosome 11 is a subject to frequent translocation and participation in fusion proteins associated with myeloid or lymphoid leukaemia. The most common fusion partners in AML (of at least 54) are AF4 and AF9. MLL encodes a transcriptional regulator with two subunits: one is a transcriptional activator with histone methyltransferase activity, and an ability to recruit HATs, while the other has DNA methyltransferase homology, interacts with HDACs and is transcriptionally repressive [210-213]. The fusion proteins exert their proleukaemic effect through a gain of function effect on the MLL component of the fusion protein, and up regulation of Hox genes otherwise repressed by a normally functioning MLL complex [212-214]. The effect of HDACi in this context is unpredictable given the multiple potential epigenetic effects of the MLL complex [215]. P21dependent cell cycle arrest and apoptosis has been observed in MLL/AF9 AML cells after treatment with valproate, [216] and we have observed a complete cytogenetic response to panobinostat in a patient with a MLL/CBP fusion protein-associated AML [217]. Further studies using in-vivo models are needed.

\section{Conclusion}

The last decade of the research into HDACi has been one where dogma around their effects and targets are continually being challenged and refined. No longer can the HDACi be regarded as simple activators of transcription, or agents that achieve their activity predominantly through direct effects on the pathways of apoptosis. Apart from induction of cell death,

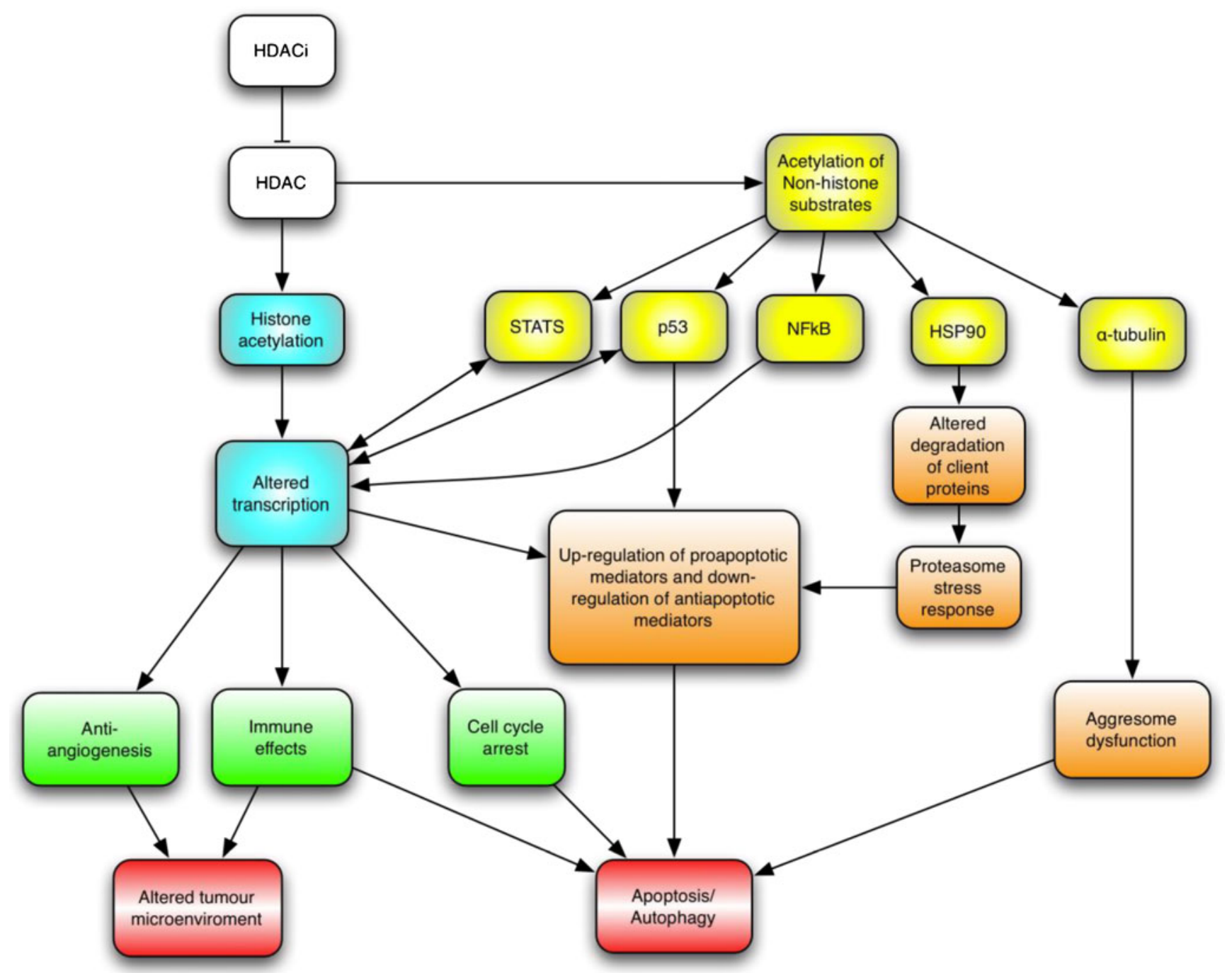

Fig. 1 Simplified schema of a selection of HDACi targets and downstream effects 
these agents have complex effects on p53 and on cytokine signaling pathways, and must now be considered immunemodifiers as well as anti-angiogenic agents. Alteration of transcription is only one mechanism but non-histone targets are clearly critically important and we need more information on the effects on the host environment (Fig. 1).

One example of the challenges we face in developing these compounds is the developing story of HDAC6; tantalizing evidence that specific HDACs (such as HDAC6) make rational targets for drug development must be tempered by evidence that the targets of HDAC6 may not actually be necessary for clinical synergy with the drugs such as the proteasome inhibitors. Another challenge is to determine if HDACi can contribute to the therapy of AML with recurrent cytogenetic abnormalities.

The work now is to better dissect which on-target effects are most critical for HDACi efficacy, in which specific clinical situations, and how we may overcome the relatively modest single agent response rates using rational combination therapies $[218,219]$.

In vitro models do not replicate the tumor microenvironment or the immune milieu and therefore probably do not, alone, provide sufficient basis for clinical studies. A greater emphasis on immune-competent in vivo models and biomarker studies are essential to establish which targets are critical in patients, and which combinations will be the most promising.

Acknowledgements Michael Dickinson is supported by a Victorian Cancer Agency Translational Research Grant and this work is presented on behalf of the Victorian Epigenetics Group.

Conflict of interest Michael Dickinson: No conflict of interests

H. Miles Prince: Medical Advisory to Novartis, Merck. Gloucester Pharmaceuticals and Celgene.

Ricky W. Johnstone: The Johnstone Lab receives grant support from Novartis to study the anti-cancer effects of panobinostat.

Logistical support during submission of this article was provided by Springer Healthcare LLC. This support was funded by Novartis.

Open Access This article is distributed under the terms of the Creative Commons Attribution Noncommercial License which permits any noncommercial use, distribution, and reproduction in any medium, provided the original author(s) and source are credited.

\section{References}

1. Richon VM, Sandhoff TW, Rifkind RA, Marks PA (2000) Histone deacetylase inhibitor selectively induces p21WAF1 expression and gene-associated histone acetylation. Proc Natl Acad Sci USA 97(18):10014-10019

2. Archer SY, Meng S, Shei A, Hodin RA (1998) p21(WAF1) is required for butyrate-mediated growth inhibition of human colon cancer cells. Proc Natl Acad Sci USA 95(12):67916796
3. Sasakawa Y, Naoe Y, Inoue T, Sasakawa T, Matsuo M, Manda T, Mutoh S (2002) Effects of FK228, a novel histone deacetylase inhibitor, on human lymphoma U-937 cells in vitro and in vivo. Biochem Pharmacol 64(7):1079-1090

4. Shao Y, Gao Z, Marks PA, Jiang X (2004) Apoptotic and autophagic cell death induced by histone deacetylase inhibitors. Proc Natl Acad Sci USA 101(52):18030-18035. doi:10.1073/ pnas.0408345102

5. Carew JS, Nawrocki ST, Kahue CN, Zhang H, Yang C, Chung L, Houghton JA, Huang P, Giles FJ, Cleveland JL (2007) Targeting autophagy augments the anticancer activity of the histone deacetylase inhibitor SAHA to overcome Bcr-Ablmediated drug resistance. Blood 110(1):313-322

6. de Ruijter AJM, van Gennip AH, Caron HN, Kemp S, van Kuilenburg ABP (2003) Histone deacetylases (HDACs): characterization of the classical HDAC family. Biochem J 370(Pt 3):737-749. doi:10.1042/BJ20021321

7. Bolden JE, Peart MJ, Johnstone RW (2006) Anticancer activities of histone deacetylase inhibitors. Nat Rev 5(9):769-784

8. Dovey OM, Foster CT, Cowley SM (2010) Emphasizing the positive: a role for histone deacetylases in transcriptional activation. Cell Cycle 9(14):2700-2701

9. Wang Z, Zang C, Cui K, Schones D, Barski A, Peng W, Zhao K (2009) Genome-wide mapping of HATs and HDACs reveals distinct functions in active and inactive genes. Cell. doi:10.1016/ j.cell.2009.06.049

10. Bertrand P (2010) Inside HDAC with HDAC inhibitors. Eur J Med Chem. doi:10.1016/j.ejmech.2010.02.030

11. Boyault C, Sadoul K, Pabion M, Khochbin S (2007) HDAC6, at the crossroads between cytoskeleton and cell signaling by acetylation and ubiquitination. Oncogene 26(37):5468-5476. doi:10.1038/sj.onc.1210614

12. Hubbert C, Guardiola A, Shao R, Kawaguchi Y, Ito A, Nixon A, Yoshida M, Wang X-F, Yao T-P (2002) HDAC6 is a microtubule-associated deacetylase. Nature 417(6887):455-458. doi: $10.1038 / 417455$ a

13. Kaufmann SH, Steensma DP (2005) On the TRAIL of a new therapy for leukemia. Leukemia 19(12):2195-2202. doi:10.1038/ sj.leu.2403946

14. Insinga A, Monestiroli S, Ronzoni S, Gelmetti V, Marchesi F, Viale A, Altucci L, Nervi C, Minucci S, Pelicci PG (2005) Inhibitors of histone deacetylases induce tumor-selective apoptosis through activation of the death receptor pathway. Nat Med 11(1):71-76. doi:10.1038/nm1160

15. Rosato RR, Almenara JA, Dai Y, Grant S (2003) Simultaneous activation of the intrinsic and extrinsic pathways by histone deacetylase (HDAC) inhibitors and tumor necrosis factor-related apoptosis-inducing ligand (TRAIL) synergistically induces mitochondrial damage and apoptosis in human leukemia cells. Mol Cancer Ther 2(12):1273-1284

16. Nakata S, Yoshida T, Horinaka M, Shiraishi T, Wakada M, Sakai $\mathrm{T}$ (2004) Histone deacetylase inhibitors upregulate death receptor 5/TRAIL-R2 and sensitize apoptosis induced by TRAIL/APO2-L in human malignant tumor cells. Oncogene 23 (37):6261-6271. doi:10.1038/sj.onc. 1207830

17. Fandy TE, Shankar S, Ross DD, Sausville E, Srivastava RK (2005) Interactive effects of HDAC inhibitors and TRAIL on apoptosis are associated with changes in mitochondrial functions and expressions of cell cycle regulatory genes in multiple myeloma. Neoplasia 7(7):646-657

18. Nebbioso A, Clarke N, Voltz E, Germain E, Ambrosino C, Bontempo P, Alvarez R, Schiavone EM, Ferrara F, Bresciani F, Weisz A, de Lera AR, Gronemeyer H, Altucci L (2005) Tumor-selective action of HDAC inhibitors involves TRAIL induction in acute myeloid leukemia cells. Nat Med 11(1):7784 
19. Klener P, Molinsky J, Simonova T, Necas E, Andera L, Zivny J (2008) Acquired resistance to tumor necrosis factor-related apoptosis- inducing ligand (TRAIL): histone deacetylase inhibitors resensitize TRAIL-resistant Jurkat acute lymphocytic leukemia cells. ASH Annu Meet Abstr 112(11):5032 EP -

20. MacFarlane M, Harper N, Snowden RT, Dyer MJ, Barnett GA, Pringle JH, Cohen GM (2002) Mechanisms of resistance to TRAILinduced apoptosis in primary B cell chronic lymphocytic leukaemia. Oncogene 21(44):6809-6818. doi:10.1038/sj.onc. 1205853

21. Inoue S, Harper N, Walewska R, Dyer MJS, Cohen GM (2009) Enhanced Fas-associated death domain recruitment by histone deacetylase inhibitors is critical for the sensitization of chronic lymphocytic leukemia cells to TRAIL-induced apoptosis. Mol Cancer Ther 8(11):3088-3097. doi:10.1158/1535-7163.MCT-090451

22. Inoue $\mathrm{S}$, MacFarlane $\mathrm{M}$, Harper $\mathrm{N}$, Wheat LMC, Dyer MJS, Cohen GM (2004) Histone deacetylase inhibitors potentiate TNF-related apoptosis-inducing ligand (TRAIL)-induced apoptosis in lymphoid malignancies. Cell Death Differ 11(Suppl 2): S193-S206. doi:10.1038/sj.cdd.4401535

23. Inoue S, Twiddy D, Dyer MJS, Cohen GM (2006) Upregulation of TRAIL-R2 is not involved in HDACi mediated sensitization to TRAIL-induced apoptosis. Cell Death Differ 13(12):2160 2162. doi:10.1038/sj.cdd. 4401977

24. Guo F, Sigua C, Tao J, Bali P, George P, Li Y, Wittmann S, Moscinski L, Atadja P, Bhalla K (2004) Cotreatment with histone deacetylase inhibitor LAQ824 enhances Apo-2L/tumor necrosis factor-related apoptosis inducing ligand-induced death inducing signaling complex activity and apoptosis of human acute leukemia cells. Cancer Res 64(7):2580-2589

25. Wood TE, Dalili S, Simpson CD, Sukhai MA, Hurren R, Anyiwe K, Mao X, Suarez Saiz F, Gronda M, Eberhard Y, MacLean N, Ketela T, Reed JC, Moffat J, Minden MD, Batey RA, Schimmer AD (2010) Selective inhibition of histone deacetylases sensitizes malignant cells to death receptor ligands. Mol Cancer Ther 9 (1):246-256. doi:10.1158/1535-7163.MCT-09-0495

26. Sanda T, Okamoto T, Uchida Y, Nakagawa H, Iida S, Kayukawa S, Suzuki T, Oshizawa T, Suzuki T, Miyata N, Ueda R (2007) Proteome analyses of the growth inhibitory effects of NCH-51, a novel histone deacetylase inhibitor, on lymphoid malignant cells. Leuk Official Journal Leuk Soc Am Leuk Res Fund UK 21 (11):2344-2353. doi:10.1038/sj.leu.2404902

27. Lucas DM, Davis ME, Parthun MR, Mone AP, Kitada S, Cunningham KD, Flax EL, Wickham J, Reed JC, Byrd JC, Grever MR (2004) The histone deacetylase inhibitor MS-275 induces caspase-dependent apoptosis in B-cell chronic lymphocytic leukemia cells. Leuk Official Journal Leuk Soc Am Leuk Res Fund UK 18(7):1207-1214. doi:10.1038/sj. leu. 2403388

28. Lucas DM, Alinari L, West DA, Davis ME, Edwards RB, Johnson AJ, Blum KA, Hofmeister CC, Freitas MA, Parthun MR, Wang D, Lehman A, Zhang X, Jarjoura D, Kulp SK, Croce CM, Grever MR, Chen C-S, Baiocchi RA, Byrd JC (2010) The novel deacetylase inhibitor AR-42 demonstrates pre-clinical activity in B-cell malignancies in vitro and in vivo. PLoS ONE 5(6):e10941. doi:10.1371/journal.pone.0010941

29. Tang R, Faussat A-M, Majdak P, Perrot J-Y, Chaoui D, Legrand O, Marie J-P (2004) Valproic acid inhibits proliferation and induces apoptosis in acute myeloid leukemia cells expressing Pgp and MRP1. Leuk Official Journal Leuk Soc Am Leuk Res Fund UK 18(7):1246-1251. doi:10.1038/sj.leu.2403390

30. Morales JC, Ruiz-Magaña MJ, Carranza D, Ortiz-Ferrón G, Ruiz-Ruiz C (2010) HDAC inhibitors with different gene regulation activities depend on the mitochondrial pathway for the sensitization of leukemic T cells to TRAIL-induced apoptosis. Cancer Lett. doi:10.1016/j.canlet.2010.04.029
31. Frew AJ, Lindemann RK, Martin BP, Clarke CJP, Sharkey J, Anthony DA, Banks K-M, Haynes NM, Gangatirkar P, Stanley K, Bolden JE, Takeda K, Yagita H, Secrist JP, Smyth MJ, Johnstone RW (2008) Combination therapy of established cancer using a histone deacetylase inhibitor and a TRAIL receptor agonist. Proc Natl Acad Sci USA 105(32):11317-11322. doi:10.1073/pnas.0801868105

32. Lindemann RK, Newbold A, Whitecross KF, Cluse LA, Frew AJ, Ellis L, Williams S, Wiegmans AP, Dear AE, Scott CL, Pellegrini M, Wei A, Richon VM, Marks PA, Lowe SW, Smyth MJ, Johnstone RW (2007) Analysis of the apoptotic and therapeutic activities of histone deacetylase inhibitors by using a mouse model of B cell lymphoma. Proc Natl Acad Sci USA 104(19):8071-8076. doi:10.1073/pnas.0702294104

33. Ellis L, Bots M, Lindemann RK, Bolden JE, Newbold A, Cluse LA, Scott CL, Strasser A, Atadja P, Lowe SW, Johnstone RW (2009) The histone deacetylase inhibitors LAQ824 and LBH589 do not require death receptor signaling or a functional apoptosome to mediate tumor cell death or therapeutic efficacy. Blood 114(2):380-393. doi:10.1182/blood-2008-10-182758

34. Chipuk JE, Moldoveanu T, Llambi F, Parsons MJ, Green DR (2010) The BCL-2 family reunion. Mol Cell 37(3):299-310. doi:10.1016/j.molcel.2010.01.025

35. Zhang XD, Gillespie SK, Borrow JM, Hersey P (2004) The histone deacetylase inhibitor suberic bishydroxamate regulates the expression of multiple apoptotic mediators and induces mitochondria-dependent apoptosis of melanoma cells. Mol Cancer Ther 3(4):425-435

36. Romanski A, Bacic B, Bug G, Pfeifer H, Gul H, Remiszewski S, Hoelzer D, Atadja P, Ruthardt M, Ottmann OG (2004) Use of a novel histone deacetylase inhibitor to induce apoptosis in cell lines of acute lymphoblastic leukemia. Haematologica 89(4):419-426

37. Mitsiades CS, Mitsiades NS, McMullan CJ, Poulaki V, Shringarpure R, Hideshima T, Akiyama M, Chauhan D, Munshi N, Gu X, Bailey C, Joseph M, Libermann TA, Richon VM, Marks PA, Anderson KC (2004) Transcriptional signature of histone deacetylase inhibition in multiple myeloma: biological and clinical implications. Proc Natl Acad Sci USA 101 (2):540-545. doi:10.1073/pnas.2536759100

38. Wozniak MB, Villuendas R, Bischoff JR, Aparicio CB, Martínez Leal JF, de La Cueva P, Rodriguez ME, Herreros B, Martin-Perez D, Longo MI, Herrera M, Piris MA, Ortiz-Romero PL (2010) Vorinostat interferes with the signaling transduction pathway of Tcell receptor and synergizes with phosphoinositide-3 kinase inhibitors in cutaneous T-cell lymphoma. Haematologica 95 (4):613-621. doi:10.3324/haematol.2009.013870

39. Khan SB, Maududi T, Barton K, Ayers J, Alkan S (2004) Analysis of histone deacetylase inhibitor, depsipeptide (FR901228), effect on multiple myeloma. Br J Haematol 125 (2):156-161. doi:10.1111/j.1365-2141.2004.04882.x

40. Peart MJ, Smyth GK, van Laar RK, Bowtell DD, Richon VM, Marks PA, Holloway AJ, Johnstone RW (2005) Identification and functional significance of genes regulated by structurally different histone deacetylase inhibitors. Proc Natl Acad Sci USA 102(10):3697-3702. doi:10.1073/pnas. 0500369102

41. Buglio D, Georgakis GV, Hanabuchi S, Arima K, Khaskhely NM, Liu Y-J, Younes A (2008) Vorinostat inhibits STAT6mediated TH2 cytokine and TARC production and induces cell death in Hodgkin lymphoma cell lines. Blood 112(4):1424 1433. doi:10.1182/blood-2008-01-133769

42. Fantin VR, Loboda A, Paweletz CP, Hendrickson RC, Pierce JW, Roth JA, Li L, Gooden F, Korenchuk S, Hou XS, Harrington EA, Randolph S, Reilly JF, Ware CM, Kadin ME, Frankel SR, Richon VM (2008) Constitutive activation of signal transducers and activators of transcription predicts vorinostat resistance in 
cutaneous T-cell lymphoma. Cancer Res 68(10):3785-3794. doi:10.1158/0008-5472.CAN-07-6091

43. Zhang Y, Adachi M, Kawamura R, Imai K (2006) Bmf is a possible mediator in histone deacetylase inhibitors FK228 and CBHA-induced apoptosis. Cell Death Differ 13(1):129-140. doi:10.1038/sj.cdd.4401686

44. Wei Y, Kadia T, Tong W, Zhang M, Jia Y, Yang H, Hu Y, Tambaro FP, Viallet J, O'brien S, Garcia-Manero G (2010) The combination of a histone deacecetylase inhibitor with the BH3Mimetic GX15-070 has synergistic antileukemia activity by activating both apoptosis and autophagy. Clin Cancer Res. doi:10.1158/1078-0432.CCR-10-0032

45. Maiso P, Carvajal-Vergara X, Ocio EM, López-Pérez R, Mateo G, Gutiérrez N, Atadja P, Pandiella A, San Miguel JF (2006) The histone deacetylase inhibitor LBH589 is a potent antimyeloma agent that overcomes drug resistance. Cancer Res 66(11):57815789. doi:10.1158/0008-5472.CAN-05-4186

46. Chen J, Fiskus W, Eaton K, Fernandez P, Wang Y, Rao R, Lee P, Joshi R, Yang Y, Kolhe R, Balusu R, Chappa P, Natarajan K, Jillella A, Atadja P, Bhalla KN (2009) Cotreatment with BCL-2 antagonist sensitizes cutaneous T-cell lymphoma to lethal action of HDAC7-Nur77-based mechanism. Blood 113(17):4038-4048. doi:10.1182/blood-2008-08-176024

47. High LM, Szymanska B, Wilczynska-Kalak U, Barber N, O'Brien R, Khaw SL, Vikstrom IB, Roberts AW, Lock RB (2009) The BH3-mimetic ABT-737 targets the apoptotic machinery in acute lymphoblastic leukemia resulting in synergistic in vitro and in vivo interactions with established drugs. Mol Pharmacol. doi:10.1124/mol.109.060780

48. Peart MJ, Tainton KM, Ruefli AA, Dear AE, Sedelies KA, O'Reilly LA, Waterhouse NJ, Trapani JA, Johnstone RW (2003) Novel mechanisms of apoptosis induced by histone deacetylase inhibitors. Cancer Res 63(15):4460-4471

49. Shao W, Growney JD, Feng Y, O'Connor G, Pu M, Zhu W, Yao Y-M, Kwon P, Fawell S, Atadja P (2010) Activity of deacetylase inhibitor panobinostat (LBH589) in cutaneous T-cell lymphoma models: defining molecular mechanisms of resistance. Int $\mathrm{J}$ Cancer J Int Cancer. doi:10.1002/ijc.25218

50. Ellis L, Pan Y, Smyth GK, George DJ, McCormack C, WilliamsTruax R, Mita M, Beck J, Burris H, Ryan G, Atadja P, Butterfoss D, Dugan M, Culver K, Johnstone RW, Prince HM (2008) Histone deacetylase inhibitor panobinostat induces clinical responses with associated alterations in gene expression profiles in cutaneous T-cell lymphoma. Clin Cancer Res 14(14):4500 4510. doi:10.1158/1078-0432.ccr-07-4262

51. Ungerstedt JS, Sowa Y, Xu WS, Shao Y, Dokmanovic M, Perez G, Ngo L, Holmgren A, Jiang X, Marks PA (2005) Role of thioredoxin in the response of normal and transformed cells to histone deacetylase inhibitors. Proc Natl Acad Sci USA 102 (3):673-678. doi:10.1073/pnas.0408732102

52. Rosato RR, Almenara JA, Grant S (2003) The histone deacetylase inhibitor MS-275 promotes differentiation or apoptosis in human leukemia cells through a process regulated by generation of reactive oxygen species and induction of $\mathrm{p} 21 \mathrm{CIP} 1 /$ WAF1 1. Cancer Res 63(13):3637-3645

53. Rosato RR, Maggio SC, Almenara JA, Payne SG, Atadja P, Spiegel S, Dent P, Grant S (2006) The histone deacetylase inhibitor LAQ824 induces human leukemia cell death through a process involving XIAP down-regulation, oxidative injury, and the acid sphingomyelinase-dependent generation of ceramide. Mol Pharmacol 69(1):216-225. doi:10.1124/mol.105.017145

54. Rosato RR, Kolla SS, Hock SK, Almenara JA, Patel A, Amin S, Atadja P, Fisher PB, Dent P, Grant S (2010) Histone deacetylase inhibitors activate NF-kappaB in human leukemia cells through an ATM/NEMO-related pathway. J Biol Chem 285(13):1006410077. doi:10.1074/jbc.M109.095208
55. Ruefli AA, Ausserlechner MJ, Bernhard D, Sutton VR, Tainton KM, Kofler R, Smyth MJ, Johnstone RW (2001) The histone deacetylase inhibitor and chemotherapeutic agent suberoylanilide hydroxamic acid (SAHA) induces a cell-death pathway characterized by cleavage of bid and production of reactive oxygen species. Proc Natl Acad Sci USA 98(19):10833-10838. doi:10.1073/pnas.191208598

56. Hu Y, Lu W, Chen G, Zhang H, Jia Y, Wei Y, Yang H, Zhang W, Fiskus W, Bhalla K, Keating M, Huang P, Garcia-Manero G (2010) Overcoming resistance to histone deacetylase inhibitors in human leukemia with the redox modulating compound \{beta\}-phenylethyl isothiocyanate. Blood. doi:10.1182/blood-2009-11-256354

57. Butler LM, Zhou X, Xu WS, Scher HI, Rifkind RA, Marks PA, Richon VM (2002) The histone deacetylase inhibitor SAHA arrests cancer cell growth, up-regulates thioredoxin-binding protein-2, and down-regulates thioredoxin. Proc Natl Acad Sci USA 99(18):11700-11705. doi:10.1073/pnas.182372299

58. Rodriguez-Gonzalez A, Lin T, Ikeda AK, Simms-Waldrip T, Fu C, Sakamoto KM (2008) Role of the aggresome pathway in cancer: targeting histone deacetylase 6-dependent protein degradation. Cancer Res 68(8):2557-2560. doi:10.1158/0008-5472. CAN-07-5989

59. Davenport EL, Morgan GJ, Davies FE (2008) Untangling the unfolded protein response. Cell Cycle 7(7):865-869

60. Ron D, Walter P (2007) Signal integration in the endoplasmic reticulum unfolded protein response. Nat Rev Mol Cell Biol 8 (7):519-529. doi:10.1038/nrm2199

61. Davenport EL, Moore HE, Dunlop AS, Sharp SY, Workman P, Morgan GJ, Davies FE (2007) Heat shock protein inhibition is associated with activation of the unfolded protein response pathway in myeloma plasma cells. Blood 110(7): 2641-2649

62. Kopito RR (2003) The missing linker: an unexpected role for a histone deacetylase. Mol Cell 12(6):1349-1351

63. Kawaguchi Y, Kovacs JJ, McLaurin A, Vance JM, Ito A, Yao TP (2003) The deacetylase HDAC6 regulates aggresome formation and cell viability in response to misfolded protein stress. Cell 115(6):727-738

64. Zhao Z, Xu H, Gong W (2009) Histone Deacetylase 6 (HDAC6) is an Independent Deacetylase for alpha-Tubulin. Protein Pept Lett

65. Hideshima T, Bradner JE, Wong J, Chauhan D, Richardson P, Schreiber SL, Anderson KC (2005) Small-molecule inhibition of proteasome and aggresome function induces synergistic antitumor activity in multiple myeloma. Proc Natl Acad Sci USA 102(24):8567-8572

66. Wang Y, Wang S-Y, Zhang X-H, Zhao M, Hou C-M, Xu Y-J, Du Z-Y, Yu X-D (2007) FK228 inhibits Hsp90 chaperone function in K562 cells via hyperacetylation of Hsp70. Biochem Biophys Res Commun 356(4):998-1003. doi:10.1016/j.bbrc.2007.03.076

67. Bali P, Pranpat M, Bradner J, Balasis M, Fiskus W, Guo F, Rocha K, Kumaraswamy S, Boyapalle S, Atadja P, Seto E, Bhalla K (2005) Inhibition of histone deacetylase 6 acetylates and disrupts the chaperone function of heat shock protein 90: a novel basis for antileukemia activity of histone deacetylase inhibitors. J Biol Chem 280(29):26729-26734. doi:10.1074/ jbc.C500186200

68. Rao R, Nalluri S, Fiskus W, Savoie A, Buckley KM, Ha K, Balusu R, Joshi A, Coothankandaswamy V, Tao J, Sotomayor E, Atadja PW, Bhalla KN (2010) Role of C/EBP homologous protein (CHOP) in panobinostat-mediated potentiation of bortezomib-induced lethal ER stress in mantle cell lymphoma cells. Clin Cancer Res. doi:10.1158/1078-0432.CCR-10-0529

69. Prabhala RH, Pelluru D, Fulciniti M, Prabhala HK, Nanjappa P, Song W, Pai C, Amin S, Tai Y-T, Richardson PG, Ghobrial IM, Treon SP, Daley JF, Anderson KC, Kutok JL, Munshi NC (2010) 
Elevated IL-17 produced by TH17 cells promotes myeloma cell growth and inhibits immune function in multiple myeloma. Blood 115(26):5385-5392. doi:10.1182/blood-2009-10-246660

70. Rao R, Fiskus W, Yang Y, Lee P, Joshi R, Fernandez P, Mandawat A, Atadja P, Bradner JE, Bhalla K (2008) HDAC6 inhibition enhances 17-AAG-mediated abrogation of hsp90 chaperone function in human leukemia cells. Blood 112 (5):1886-1893. doi:10.1182/blood-2008-03-143644

71. Catley L, Weisberg E, Kiziltepe T, Tai YT, Hideshima T, Neri P, Tassone P, Atadja P, Chauhan D, Munshi NC, Anderson KC (2006) Aggresome induction by proteasome inhibitor bortezomib and alpha-tubulin hyperacetylation by tubulin deacetylase (TDAC) inhibitor LBH589 are synergistic in myeloma cells. Blood 108(10):3441-3449

72. Fotheringham S, Epping MT, Stimson L, Khan O, Wood V, Pezzella F, Bernards R, La Thangue NB (2009) Genome-wide loss-of-function screen reveals an important role for the proteasome in HDAC inhibitor-induced apoptosis. Cancer Cell 15(1):57-66. doi:10.1016/j.ccr.2008.12.001

73. Khan O, Fotheringham S, Wood V, Stimson L, Zhang C, Pezzella F, Duvic M, Kerr DJ, La Thangue NB (2010) HR23B is a biomarker for tumor sensitivity to HDAC inhibitor-based therapy. Proc Natl Acad Sci USA 107(14):6532-6537. doi:10.1073/pnas.0913912107

74. Boyault C, Zhang Y, Fritah S, Caron C, Gilquin B, Kwon SH, Garrido C, Yao T-P, Vourc'h C, Matthias P, Khochbin S (2007) HDAC6 controls major cell response pathways to cytotoxic accumulation of protein aggregates. Genes Dev 21(17):21722181. doi:10.1101/gad.436407

75. Ocio EM, Vilanova D, Atadja P, Maiso P, Crusoe E, FernándezLázaro D, Garayoa M, San-Segundo L, Hernández-Iglesias T, de Álava E, Shao W, Yao Y-M, Pandiella A, San-Miguel JF (2009) In vitro and in vivo rationale for the triple combination of panobinostat (LBH589) and dexamethasone with either bortezomib or lenalidomide in multiple myeloma. Haematologica. doi:10.3324/haematol.2009.015495

76. Buglio D, Mamidipudi V, Khaskhely NM, Brady H, Heise C, Besterman J, Martell RE, MacBeth K, Younes A (2010) The class-I HDAC inhibitor MGCD0103 induces apoptosis in Hodgkin lymphoma cell lines and synergizes with proteasome inhibitors by an HDAC6-independent mechanism. Br J Haematol Epub

77. Harrison S, Quach H, Yuen K, Strayer A, Copeman M, Peinert S, Bishton M, Wolf M, Januszewicz H, Kenealy M, Herbert K, Westerman D, Carney D, Seymour J, Johnstone R, Ritchie D, Prince M (2008) High response rates with the combination of bortezomib, dexamethasone and the pan-histone deacetylase inhibitor romidepsin in patients with relapsed or refractory multiple myeloma in a phase I/II clinical trial. ASH Annu Meet Abstr 112(11):3698 EP -

78. Piekarz RL, Frye R, Turner M, Wright JJ, Allen SL, Kirschbaum MH, Zain J, Prince HM, Leonard JP, Geskin LJ, Reeder C, Joske D, Figg WD, Gardner ER, Steinberg SM, Jaffe ES, Stetler-Stevenson M, Lade S, Fojo AT, Bates SE (2009) Phase II multi-institutional trial of the histone deacetylase inhibitor romidepsin as monotherapy for patients with cutaneous T-cell lymphoma. J Clin Oncol 27(32):5410-5417. doi:10.1200/jco.2008.21.6150

79. Harris SL, Levine AJ (2005) The p53 pathway: positive and negative feedback loops. Oncogene 24(17):2899-2908. doi:10.1038/sj.onc.1208615

80. Gu W, Roeder RG (1997) Activation of p53 sequence-specific DNA binding by acetylation of the p53 C-terminal domain. Cell 90(4):595-606

81. Luo J, Su F, Chen D, Shiloh A, Gu W (2000) Deacetylation of p53 modulates its effect on cell growth and apoptosis. Nature 408(6810):377-381. doi:10.1038/35042612
82. Terui T, Murakami K, Takimoto R, Takahashi M, Takada K, Murakami T, Minami S, Matsunaga T, Takayama T, Kato J, Niitsu Y (2003) Induction of PIG3 and NOXA through acetylation of p53 at 320 and 373 lysine residues as a mechanism for apoptotic cell death by histone deacetylase inhibitors. Cancer Res 63(24):8948-8954

83. Sakaguchi K, Herrera JE, Saito S, Miki T, Bustin M, Vassilev A, Anderson CW, Appella E (1998) DNA damage activates p53 through a phosphorylation-acetylation cascade. Genes Dev 12 (18):2831-2841

84. Tang Y, Zhao W, Chen Y, Zhao Y, Gu W (2008) Acetylation is indispensable for p53 activation. Cell 133(4):612-626. doi:10.1016/j.cell.2008.03.025

85. Juan LJ, Shia WJ, Chen MH, Yang WM, Seto E, Lin YS, Wu CW (2000) Histone deacetylases specifically down-regulate p53-dependent gene activation. J Biol Chem 275(27):2043620443

86. Spange S, Wagner T, Heinzel T, Krämer OH (2009) Acetylation of non-histone proteins modulates cellular signalling at multiple levels. Int J Biochem Cell Biol 41(1):185-198. doi:10.1016/j. biocel.2008.08.027

87. Palani CD, Beck JF, Sonnemann J (2010) Histone deacetylase inhibitors enhance the anticancer activity of nutlin-3 and induce p53 hyperacetylation and downregulation of MDM2 and MDM4 gene expression. Investig New Drugs. doi:10.1007/s10637-0109510-7

88. Harms KL, Chen X (2007) Histone deacetylase 2 modulates p53 transcriptional activities through regulation of $\mathrm{p} 53$-DNA binding activity. Cancer Res 67(7):3145-3152. doi:10.1158/0008-5472. CAN-06-4397

89. Zhao Y, Lu S, Wu L, Chai G, Wang H, Chen Y, Sun J, Yu Y, Zhou W, Zheng Q, Wu M, Otterson GA, Zhu W-G (2006) Acetylation of $\mathrm{p} 53$ at lysine $373 / 382$ by the histone deacetylase inhibitor depsipeptide induces expression of $\mathrm{p} 21$ (Waf1/Cip1). Mol Cell Biol 26(7):2782-2790. doi:10.1128/MCB.26.7.27822790.2006

90. Condorelli F, Gnemmi I, Vallario A, Genazzani AA, Canonico PL (2008) Inhibitors of histone deacetylase (HDAC) restore the p53 pathway in neuroblastoma cells. Br J Pharmacol 153 (4):657-668. doi:10.1038/sj.bjp.0707608

91. Sowa $Y$, Orita $T$, Minamikawa-Hiranabe $S$, Mizuno $T$, Nomura H, Sakai T (1999) Sp3, but not Sp1, mediates the transcriptional activation of the $\mathrm{p} 21 / \mathrm{WAF} 1 / \mathrm{Cip} 1$ gene promoter by histone deacetylase inhibitor. Cancer Res 59 (17):4266-4270

92. Saito A, Yamashita T, Mariko Y, Nosaka Y, Tsuchiya K, Ando T, Suzuki T, Tsuruo T, Nakanishi O (1999) A synthetic inhibitor of histone deacetylase, MS-27-275, with marked in vivo antitumor activity against human tumors. Proc Natl Acad Sci USA 96 (8):4592-4597

93. Gui C-Y, Ngo L, Xu WS, Richon VM, Marks PA (2004) Histone deacetylase (HDAC) inhibitor activation of p21WAF1 involves changes in promoter-associated proteins, including HDAC1. Proc Natl Acad Sci USA 101(5):1241-1246. doi:10.1073/ pnas. 0307708100

94. Johnstone RW, Licht JD (2003) Histone deacetylase inhibitors in cancer therapy: is transcription the primary target? Cancer Cell 4 (1):13-18

95. Marks PA, Richon VM, Rifkind RA (2000) Histone deacetylase inhibitors: inducers of differentiation or apoptosis of transformed cells. J Natl Cancer Inst 92(15):1210-1216

96. Sandor V, Senderowicz A, Mertins S, Sackett D, Sausville E, Blagosklonny MV, Bates SE (2000) P21-dependent g(1)arrest with downregulation of cyclin D1 and upregulation of cyclin E by the histone deacetylase inhibitor FR901228. Br J Cancer 83 (6):817-825. doi:10.1054/bjoc.2000.1327 
97. Kawamata N, Chen J, Koeffler HP (2007) Suberoylanilide hydroxamic acid (SAHA; vorinostat) suppresses translation of cyclin D1 in mantle cell lymphoma cells. Blood 110(7):26672673. doi:10.1182/blood-2005-11-026344

98. Burgess A, Ruefli A, Beamish H, Warrener R, Saunders N, Johnstone R, Gabrielli B (2004) Histone deacetylase inhibitors specifically kill nonproliferating tumour cells. Oncogene 23 (40):6693-6701. doi:10.1038/sj.onc. 1207893

99. Burgess AJ, Pavey S, Warrener R, Hunter LJ, Piva TJ, Musgrove EA, Saunders N, Parsons PG, Gabrielli BG (2001) Up-regulation of p21(WAF1/CIP1) by histone deacetylase inhibitors reduces their cytotoxicity. Mol Pharmacol 60 (4):828-837

100. Mitchell TJ, John S (2005) Signal transducer and activator of transcription (STAT) signalling and T-cell lymphomas. Immunology 114(3):301-312. doi:10.1111/j.1365-2567. 2005.02091.x

101. Paulson M, Pisharody S, Pan L, Guadagno S, Mui AL, Levy DE (1999) Stat protein transactivation domains recruit p300/CBP through widely divergent sequences. J Biol Chem 274 (36):25343-25349

102. Nusinzon I, Horvath CM (2003) Interferon-stimulated transcription and innate antiviral immunity require deacetylase activity and histone deacetylase 1. Proc Natl Acad Sci USA 100 (25):14742-14747. doi:10.1073/pnas.2433987100

103. Nusinzon I, Horvath CM (2005) Unexpected roles for deacetylation in interferon- and cytokine-induced transcription. J Interferon Cytokine Res 25(12):745-748. doi:10.1089/ jir.2005.25.745

104. Rascle A, Johnston JA, Amati B (2003) Deacetylase activity is required for recruitment of the basal transcription machinery and transactivation by STAT5. Mol Cell Biol 23(12):4162-4173

105. Klampfer L, Huang J, Swaby L-A, Augenlicht L (2004) Requirement of histone deacetylase activity for signaling by STAT1. J Biol Chem 279(29):30358-30368. doi:10.1074/jbc. M401359200

106. Yu H, Pardoll D, Jove R (2009) STATs in cancer inflammation and immunity: a leading role for STAT3. Nat Rev Cancer 9 (11):798. doi:10.1038/nrc2734

107. Chatterjee M, Stühmer T, Herrmann P, Bommert K, Dörken B, Bargou RC (2004) Combined disruption of both the MEK/ERK and the IL-6R/STAT3 pathways is required to induce apoptosis of multiple myeloma cells in the presence of bone marrow stromal cells. Blood 104(12):3712-3721. doi:10.1182/blood2004-04-1670

108. Chatterjee M, Jain S, Stühmer T, Andrulis M, Ungethüm U, Kuban R-J, Lorentz H, Bommert K, Topp M, Krämer D, MüllerHermelink HK, Einsele H, Greiner A, Bargou RC (2007) STAT3 and MAPK signaling maintain overexpression of heat shock proteins 90alpha and beta in multiple myeloma cells, which critically contribute to tumor-cell survival. Blood 109(2):720728. doi:10.1182/blood-2006-05-024372

109. Löffler D, Brocke-Heidrich K, Pfeifer G, Stocsits C, Hackermüller J, Kretzschmar AK, Burger R, Gramatzki M, Blumert C, Bauer K, Cvijic H, Ullmann AK, Stadler PF, Horn F (2007) Interleukin-6 dependent survival of multiple myeloma cells involves the Stat3-mediated induction of microRNA-21 through a highly conserved enhancer. Blood 110(4):1330-1333. doi:10.1182/blood-2007-03-081133

110. Alas S, Bonavida B (2003) Inhibition of constitutive STAT3 activity sensitizes resistant non-Hodgkin's lymphoma and multiple myeloma to chemotherapeutic drug-mediated apoptosis. Clin Cancer Res 9(1):316-326

111. García JF, Camacho FI, Morente M, Fraga M, Montalbán C, Alvaro T, Bellas C, Castaño A, Díez A, Flores T, Martin C, Martinez MA, Mazorra F, Menárguez J, Mestre MJ, Mollejo M, Sáez AI, Sánchez L, Piris MA, Group SHLS (2003) Hodgkin and
Reed-Sternberg cells harbor alterations in the major tumor suppressor pathways and cell-cycle checkpoints: analyses using tissue microarrays. Blood 101(2):681-689. doi:10.1182/blood2002-04-1128

112. Lamprecht B, Kreher S, Anagnostopoulos I, Jöhrens K, Monteleone G, Jundt F, Stein H, Janz M, Dörken B, Mathas S (2008) Aberrant expression of the Th2 cytokine IL-21 in Hodgkin lymphoma cells regulates STAT3 signaling and attracts Treg cells via regulation of MIP-3alpha. Blood 112(8):33393347. doi:10.1182/blood-2008-01-134783

113. Baus D, Pfitzner E (2006) Specific function of STAT3, SOCS1, and SOCS3 in the regulation of proliferation and survival of classical Hodgkin lymphoma cells. Int J Cancer 118(6):14041413. doi:10.1002/ijc. 21539

114. Tsuyama N, Danjoh I, Otsuyama K-I, Obata M, Tahara H, Ohta T, Ishikawa H (2005) IL-6-induced Bcl6 variant 2 supports IL-6dependent myeloma cell proliferation and survival through STAT3. Biochem Biophys Res Commun 337(1):201-208. doi:10.1016/j.bbrc.2005.09.036

115. Daigle D, Megyola C, El-Guindy A, Gradoville L, Tuck D, Miller G, Bhaduri-McIntosh S (2010) Upregulation of STAT3 marks Burkitt lymphoma cells refractory to Epstein-Barr virus lytic cycle induction by HDAC inhibitors. J Virol 84(2):9931004. doi:10.1128/JVI.01745-09

116. Lam LT, Wright G, Davis RE, Lenz G, Farinha P, Dang L, Chan JW, Rosenwald A, Gascoyne RD, Staudt LM (2008) Cooperative signaling through the signal transducer and activator of transcription 3 and nuclear factor- $\{$ kappa $\} B$ pathways in subtypes of diffuse large B-cell lymphoma. Blood 111(7):3701-3713. doi:10.1182/blood-2007-09-111948

117. Eriksen KW, Kaltoft K, Mikkelsen G, Nielsen M, Zhang Q, Geisler C, Nissen MH, Röpke C, Wasik MA, Odum N (2001) Constitutive STAT3-activation in Sezary syndrome: tyrphostin AG490 inhibits STAT3-activation, interleukin-2 receptor expression and growth of leukemic Sezary cells. Leukemia 15(5):787793

118. Duvic M, Talpur R, Ni X, Zhang C, Hazarika P, Kelly C, Chiao JH, Reilly JF, Ricker JL, Richon VM, Frankel SR (2007) Phase 2 trial of oral vorinostat (suberoylanilide hydroxamic acid, SAHA) for refractory cutaneous T-cell lymphoma (CTCL). Blood 109 (1):31-39

119. Scheeren FA, Diehl SA, Smit LA, Beaumont T, Naspetti M, Bende RJ, Blom B, Karube K, Ohshima K, Van Noesel CJM, Spits H (2008) IL-21 is expressed in Hodgkin lymphoma and activates STAT5: evidence that activated STAT5 is required for Hodgkin lymphomagenesis. Blood 111(9):4706-4715. doi:10.1182/blood-2007-08-105643

120. Hinz M, Lemke P, Anagnostopoulos I, Hacker C, Krappmann D, Mathas S, Dörken B, Zenke M, Stein H, Scheidereit C (2002) Nuclear factor kappaB-dependent gene expression profiling of Hodgkin's disease tumor cells, pathogenetic significance, and link to constitutive signal transducer and activator of transcription 5a activity. J Exp Med 196(5):605-617

121. Buglio D, Georgiakis G, Hanabuchi S, Arima K, Khaskhely N, Liu Y, Younes A (2008) Vorinostat inhibits STAT6-mediated TH2 cytokine and TARC production and induces cell death in Hodgkin lymphoma cell lines. Blood. doi:10.1182/blood-200801-133769

122. Wirnsberger G, Hebenstreit D, Posselt G, Horejs-Hoeck J, Duschl A (2006) IL-4 induces expression of TARC/CCL17 via two STAT6 binding sites. Eur J Immunol 36(7):1882-1891. doi:10.1002/eji.200635972

123. Hebenstreit D, Wirnsberger G, Horejs-Hoeck J, Duschl A (2006) Signaling mechanisms, interaction partners, and target genes of STAT6. Cytokine Growth Factor Rev 17(3):173-188. doi:10.1016/j.cytogfr.2006.01.004 
124. Skinnider BF, Elia AJ, Gascoyne RD, Patterson B, Trumper L, Kapp U, Mak TW (2002) Signal transducer and activator of transcription 6 is frequently activated in Hodgkin and Reed-Sternberg cells of Hodgkin lymphoma. Blood 99 (2):618-626

125. $\mathrm{Yu} \mathrm{H}$, Jove $\mathrm{R}$ (2004) The STATs of cancer-new molecular targets come of age. Nat Rev Cancer 4(2):97-105

126. Krämer $\mathrm{OH}$, Knauer SK, Greiner G, Jandt E, Reichardt S, Gührs K-H, Stauber RH, Böhmer FD, Heinzel T (2009) A phosphorylation-acetylation switch regulates STAT1 signaling. Genes Dev 23(2):223-235. doi:10.1101/gad.479209

127. Krämer OH, Baus D, Knauer SK, Stein S, Jäger E, Stauber RH, Grez M, Pfitzner E, Heinzel T (2006) Acetylation of Stat1 modulates NF-kappaB activity. Genes Dev 20(4):473-485. doi:10.1101/gad.364306

128. Yuan Z-L, Guan Y-J, Chatterjee D, Chin YE (2005) Stat3 dimerization regulated by reversible acetylation of a single lysine residue. Science 307(5707):269-273. doi:10.1126/science. 1105166

129. Dai Y, Chen S, Kramer LB, Funk VL, Dent P, Grant S (2008) Interactions between bortezomib and romidepsin and belinostat in chronic lymphocytic leukemia cells. Clin Cancer Res 14 (2):549-558. doi:10.1158/1078-0432.CCR-07-1934

130. Zhang C, Richon V, Ni X, Talpur R, Duvic M (2005) Selective induction of apoptosis by histone deacetylase inhibitor SAHA in cutaneous T-cell lymphoma cells: relevance to mechanism of therapeutic action. J Investig Dermatol 125(5):1045-1052

131. Chen L-F, Greene WC (2004) Shaping the nuclear action of NFkappaB. Nat Rev Mol Cell Biol 5(5):392-401. doi:10.1038/ nrm1368

132. Muratani M, Tansey WP (2003) How the ubiquitin-proteasome system controls transcription. Nat Rev Mol Cell Biol 4(3):192201. doi:10.1038/nrm1049

133. Hideshima T, Ikeda H, Chauhan D, Okawa Y, Raje N, Podar K, Mitsiades C, Munshi NC, Richardson PG, Carrasco RD, Anderson KC (2009) Bortezomib induces canonical nuclear factor-kappaB activation in multiple myeloma cells. Blood 114 (5):1046-1052. doi:10.1182/blood-2009-01-199604

134. Li C, Chen S, Yue P, Deng X, Lonial S, Khuri FR, Sun S-Y (2010) The proteasome inhibitor PS-341 (Bortezomib) induces calpain-dependent I\{kappa\}B \{alpha\} degradation. J Biol Chem. doi:10.1074/jbc.M109.072694

135. Chen L-F, Greene WC (2003) Regulation of distinct biological activities of the NF-kappaB transcription factor complex by acetylation. J Mol Med 81(9):549-557. doi:10.1007/s00109-0030469-0

136. Maeda T, Towatari M, Kosugi H, Saito H (2000) Up-regulation of costimulatory/adhesion molecules by histone deacetylase inhibitors in acute myeloid leukemia cells. Blood 96(12):38473856

137. Magner WJ, Kazim AL, Stewart C, Romano MA, Catalano G, Grande C, Keiser N, Santaniello F, Tomasi TB (2000) Activation of MHC class I, II, and CD40 gene expression by histone deacetylase inhibitors. J Immunol 165(12):7017-7024

138. Khan ANH, Gregorie CJ, Tomasi TB (2008) Histone deacetylase inhibitors induce TAP, LMP, Tapasin genes and MHC class I antigen presentation by melanoma cells. Cancer Immunol Immunother 57(5):647-654. doi:10.1007/s00262-007-0402-4

139. Khan ANH, Magner WJ, Tomasi TB (2007) An epigenetic vaccine model active in the prevention and treatment of melanoma. J Transl Med 5:64. doi:10.1186/1479-5876-5-64

140. Gialitakis M, Kretsovali A, Spilianakis C, Kravariti L, Mages J, Hoffmann R, Hatzopoulos AK, Papamatheakis J (2006) Coordinated changes of histone modifications and HDAC mobilization regulate the induction of MHC class II genes by Trichostatin A. Nucleic Acids Res 34(3):765-772. doi:10.1093/nar/gkj462
141. Campoli M, Ferrone S (2008) HLA antigen changes in malignant cells: epigenetic mechanisms and biologic significance. Oncogene 27(45):5869-5885. doi:10.1038/onc.2008.273

142. Khan ANH, Tomasi TB (2008) Histone deacetylase regulation of immune gene expression in tumor cells. Immunol Res 40 (2):164-178. doi:10.1007/s12026-007-0085-0

143. Chambost H, Van Baren N, Brasseur F, Godelaine D, Xerri L, Landi SJ, Theate I, Plumas J, Spagnoli GC, Michel G, Coulie PG, Olive D (2000) Expression of gene MAGE-A4 in ReedSternberg cells. Blood 95(11):3530-3533

144. Cruz C, Leen A, Gerdemann U, Christin A, Tripic T, Shafer J, Younes A, Horton T, Shpall E, Heslop H, Rooney C, Bollard C (2009) Immune-based therapies targeting mage-A4 for relapsed/ refractory Hodgkin's lymphoma after stem cell transplant. ASH Annu Meet Abstr 114(22):4089 EP -

145. Wischnewski F, Pantel K, Schwarzenbach H (2006) Promoter demethylation and histone acetylation mediate gene expression of MAGE-A1, -A2, -A3, and -A12 in human cancer cells. Mol Cancer Res 4(5):339-349. doi:10.1158/1541-7786.MCR-05-0229

146. Shichijo S, Yamada A, Sagawa K, Iwamoto O, Sakata M, Nagai $\mathrm{K}$, Itoh K (1996) Induction of MAGE genes in lymphoid cells by the demethylating agent 5-aza-2'-deoxycytidine. Jpn J Cancer Res 87(7):751-756

147. Goodyear O, Agathanggelou A, Novitzky-Basso I, Siddique S, McSkeane T, Ryan G, Vyas P, Cavenagh J, Stankovic T, Moss P, Craddock C (2010) Induction of a CD8+ T-cell response to the MAGE cancer testis antigen by combined treatment with azacitidine and sodium valproate in patients with acute myeloid leukemia and myelodysplasia. Blood. doi:10.1182/blood-200911-249474

148. Moreno A, Szmania S, Shi J, Barlogie B, Prentice G, van Rhee F (2008) Induction of the cancer-testis antigen MAGE-A3 in myeloma cell lines by 5'azacitidine and MGCD0103. ASCO Meet Abstr 26(15_suppl):14008 EP -

149. Khaskhely NM, Buglio D, Shafer J, Bollard CM, Younes A (2009) The histone deacetylase (HDAC) inhibitor entinostat (SNDX-275) targets Hodgkin lymphoma through a dual mechanism of immune modulation and apoptosis induction. Blood ASH Annu Meet Abstr 114(22):1562-

150. Moreno-Bost A, Szmania S, Stone K, Shi J, Garg T, Shaughnessy J, Barlogie B, Prentice H, van Rhee F (2008) Recognition of myeloma by MAGE-A3 specific cytotoxic T lymphocytes induced by treatment with azacitidine and MGCD0103. ASH Annu Meet Abstr 112(11):3674 EP -

151. Stankovic T, McLarnon A, Agathanggelou A, Goodyear O, Craddock C, Moss P (2008) Epigenetic manipulation of cancer testis antigen (CTA) expression: a strategy for manipulating the graft-versus leukaemia response in patients allografted for haematological malignancies. ASH Annu Meet Abstr 112 (11):600 EP -

152. Raulet DH, Guerra N (2009) Oncogenic stress sensed by the immune system: role of natural killer cell receptors. Nat Rev Immunol 9(8):568-580. doi:10.1038/nri2604

153. Gasser S, Raulet DH (2006) Activation and self-tolerance of natural killer cells. Immunol Rev 214:130-142. doi:10.1111/ j.1600-065X.2006.00460.x

154. Armeanu S, Bitzer M, Lauer UM, Venturelli S, Pathil A, Krusch M, Kaiser S, Jobst J, Smirnow I, Wagner A, Steinle A, Salih HR (2005) Natural killer cell-mediated lysis of hepatoma cells via specific induction of NKG2D ligands by the histone deacetylase inhibitor sodium valproate. Cancer Res 65(14):6321-6329. doi:10.1158/0008-5472.CAN-04-4252

155. Skov S, Pedersen MT, Andresen L, Straten PT, Woetmann A, Odum N (2005) Cancer cells become susceptible to natural killer cell killing after exposure to histone deacetylase inhibitors due to glycogen synthase kinase-3-dependent expression of MHC class 
I-related chain A and B. Cancer Res 65(23):11136-11145. doi:10.1158/0008-5472.CAN-05-0599

156. Rohner A, Langenkamp U, Siegler U, Kalberer CP, WodnarFilipowicz A (2007) Differentiation-promoting drugs up-regulate NKG2D ligand expression and enhance the susceptibility of acute myeloid leukemia cells to natural killer cell-mediated lysis. Leuk Res 31(10):1393-1402. doi:10.1016/j.leukres.2007.02.020

157. Diermayr S, Himmelreich H, Durovic B, Mathys-Schneeberger A, Siegler U, Langenkamp U, Hofsteenge J, Gratwohl A, Tichelli A, Paluszewska M, Wiktor-Jedrzejczak W, Kalberer CP, Wodnar-Filipowicz A (2008) NKG2D ligand expression in AML increases in response to HDAC inhibitor valproic acid and contributes to allorecognition by NK-cell lines with single KIRHLA class I specificities. Blood 111(3):1428-1436. doi:10.1182/ blood-2007-07-101311

158. Lu X, Ohata K, Kondo Y, Luis Espinoza J, Qi Z, Nakao S (2009) Hydroxyurea upregulates NKG2D ligand expression in myeloid leukemia cells synergistically with valproic acid and potentially enhances susceptibility of leukemic cells to natural killer cell-mediated cytolysis. Cancer Sci. doi:10.1111/j.13497006.2009.01439.x

159. Gasser S, Orsulic S, Brown EJ, Raulet DH (2005) The DNA damage pathway regulates innate immune system ligands of the NKG2D receptor. Nature 436(7054):1186-1190. doi:10.1038/ nature 03884

160. Ritchie DS, Quach H, Fielding K, Neeson P (2010) Drugmediated and cellular immunotherapy in multiple myeloma. Immunotherapy 2(2):243-255. doi:10.2217/imt.10.9

161. Quach H, Ritchie D, Stewart AK, Neeson P, Harrison S, Smyth MJ, Prince HM (2010) Mechanism of action of immunomodulatory drugs (IMiDS) in multiple myeloma. Leukemia 24(1):2232. doi:10.1038/leu.2009.236

162. Song W, Tai Y-T, Tian Z, Hideshima T, Chauhan D, Nanjappa P, Exley M, Anderson K, Munshi N (2009) HDAC inhibition by LBH589 affects phenotype and function of human dendritic cells. ASH Annu Meet Abstr 114(22):1646 EP -

163. Nencioni A, Beck J, Werth D, Grünebach F, Patrone F, Ballestrero A, Brossart P (2007) Histone deacetylase inhibitors affect dendritic cell differentiation and immunogenicity. Clin Cancer Res 13 (13):3933-3941. doi:10.1158/1078-0432.CCR-06-2903

164. Reddy P, Sun Y, Toubai T, Duran-Struuck R, Clouthier SG, Weisiger E, Maeda Y, Tawara I, Krijanovski O, Gatza E, Liu C, Malter C, Mascagni P, Dinarello CA, Ferrara JLM (2008) Histone deacetylase inhibition modulates indoleamine 2, 3dioxygenase-dependent DC functions and regulates experimental graft-versus-host disease in mice. J Clin Invest 118(7):25622573. doi:10.1172/JCI34712

165. Skinnider BF (2002) The role of cytokines in classical Hodgkin lymphoma. Blood 99(12):4283-4297. doi:10.1182/blood-200201-0099

166. Dickinson M, Ritchie D, Deangelo DJ, Spencer A, Ottmann OG, Fischer T, Bhalla KN, Liu A, Parker K, Scott JW, Bishton M, Miles Prince H (2009) Preliminary evidence of disease response to the pan deacetylase inhibitor panobinostat (LBH589) in refractory Hodgkin Lymphoma. Br J Haematol:1-5. doi:10.1111/j.1365-2141.2009.07837.x

167. Wang L, Tao R, Hancock WW (2009) Using histone deacetylase inhibitors to enhance Foxp3 $(+)$ regulatory T-cell function and induce allograft tolerance. Immunol Cell Biol 87(3):195-202. doi:10.1038/icb.2008.106

168. Lucas JL, Mirshahpanah P, Haas-Stapleton E, Asadullah K, Zollner TM, Numerof RP (2009) Induction of Foxp3+ regulatory T cells with histone deacetylase inhibitors. Cell Immunol 257(12):97-104. doi:10.1016/j.cellimm.2009.03.004

169. Johnson J, Pahuja A, Graham M, Hering B, Hancock WW, Bansal-Pakala P (2008) Effects of histone deacetylase inhibitor
SAHA on effector and FOXP3 + regulatory $\mathrm{T}$ cells in rhesus macaques. Transplant Proc 40(2):459-461. doi:10.1016/j.transproceed.2008.01.039

170. Tao R, de Zoeten EF, Ozkaynak E, Chen C, Wang L, Porrett PM, Li B, Turka LA, Olson EN, Greene MI, Wells AD, Hancock WW (2007) Deacetylase inhibition promotes the generation and function of regulatory $\mathrm{T}$ cells. Nat Med 13(11):1299-1307. doi: $10.1038 / \mathrm{nm} 1652$

171. Ghiringhelli F, Ménard C, Martin F, Zitvogel L (2006) The role of regulatory $\mathrm{T}$ cells in the control of natural killer cells: relevance during tumor progression. Immunol Rev 214:229-238. doi:10.1111/j.1600-065X.2006.00445.x

172. Prabhala RH, Neri P, Bae JE, Tassone P, Shammas MA, Allam CK, Daley JF, Chauhan D, Blanchard E, Thatte HS, Anderson KC, Munshi NC (2006) Dysfunctional T regulatory cells in multiple myeloma. Blood 107(1):301-304. doi:10.1182/blood2005-08-3101

173. Janson PCJ, Winerdal ME, Winqvist O (2009) At the crossroads of $\mathrm{T}$ helper lineage commitment-Epigenetics points the way. Biochim Biophys Acta 1790(9):906-919. doi:10.1016/j.bbagen.2008.12.003

174. van Loosdregt J, Vercoulen Y, Guichelaar T, Gent YYJ, Beekman JM, van Beekum O, Brenkman AB, Hijnen D-J, Mutis T, Kalkhoven E, Prakken BJ, Coffer PJ (2010) Regulation of Treg functionality by acetylation-mediated Foxp3 protein stabilization. Blood 115(5):965-974. doi:10.1182/blood-2009-02-207118

175. Berger CL, Tigelaar R, Cohen J, Mariwalla K, Trinh J, Wang N, Edelson RL (2005) Cutaneous T-cell lymphoma: malignant proliferation of T-regulatory cells. Blood 105(4):1640-1647. doi:10.1182/blood-2004-06-2181

176. Li WW, Hutnik M, Gehr G (2008) Antiangiogenesis in haematological malignancies. Br J Haematol 143(5):622-631. doi:10.1111/j.1365-2141.2008.07372.x

177. Ellis L, Hammers H, Pili R (2009) Targeting tumor angiogenesis with histone deacetylase inhibitors. Cancer Lett 280(2):145-153. doi:10.1016/j.canlet.2008.11.012

178. Urbich C, Rössig L, Kaluza D, Potente M, Boeckel J-N, Knau A, Diehl F, Geng J-G, Hofmann W-K, Zeiher AM, Dimmeler S (2009) HDAC5 is a repressor of angiogenesis and determines the angiogenic gene expression pattern of endothelial cells. Blood 113(22):5669-5679. doi:10.1182/blood-2009-01-196485

179. Kim MS, Kwon HJ, Lee YM, Baek JH, Jang JE, Lee SW, Moon EJ, Kim HS, Lee SK, Chung HY, Kim CW, Kim KW (2001) Histone deacetylases induce angiogenesis by negative regulation of tumor suppressor genes. Nat Med 7(4):437-443. doi:10.1038/ 86507

180. Deroanne CF, Bonjean K, Servotte S, Devy L, Colige A, Clausse N, Blacher S, Verdin E, Foidart J-M, Nusgens BV, Castronovo V (2002) Histone deacetylases inhibitors as anti-angiogenic agents altering vascular endothelial growth factor signaling. Oncogene 21(3):427-436. doi:10.1038/sj.onc. 1205108

181. Qian DZ, Wang X, Kachhap SK, Kato Y, Wei Y, Zhang L, Atadja P, Pili R (2004) The histone deacetylase inhibitor NVP-LAQ824 inhibits angiogenesis and has a greater antitumor effect in combination with the vascular endothelial growth factor receptor tyrosine kinase inhibitor PTK787/ ZK222584. Cancer Res 64(18):6626-6634. doi:10.1158/ 0008-5472.CAN-04-0540

182. Kuljaca S, Liu T, Tee AEL, Haber M, Norris MD, Dwarte T, Marshall GM (2007) Enhancing the anti-angiogenic action of histone deacetylase inhibitors. Mol Cancer 6:68. doi:10.1186/ 1476-4598-6-68

183. Qian DZ, Kato Y, Shabbeer S, Wei Y, Verheul HMW, Salumbides B, Sanni T, Atadja P, Pili R (2006) Targeting tumor angiogenesis with histone deacetylase inhibitors: the hydroxamic acid derivative LBH589. Clin Cancer Res 12(2):634-642. doi:10.1158/1078-0432.CCR-05-1132 
184. Kwon HJ, Kim MS, Kim MJ, Nakajima H, Kim K-W (2002) Histone deacetylase inhibitor FK228 inhibits tumor angiogenesis. Int J Cancer 97(3):290-296

185. Medinger M, Mross K (2010) Clinical trials with anti-angiogenic agents in hematological malignancies. J Angiogenes Res 2:10. doi:10.1186/2040-2384-2-10

186. Aurora AB, Biyashev D, Mirochnik Y, Zaichuk TA, SánchezMartinez C, Renault M-A, Losordo D, Volpert OV (2010) NFkappaB balances vascular regression and angiogenesis via chromatin remodeling and NFAT displacement. Blood 116 (3):475-484. doi:10.1182/blood-2009-07-232132

187. Wolf J, Siegel D, Matous J, Lonial S, Goldschmidt H, Schmitt S, Vij R, De Malgalhaes-Silverman M, Abonour R, Jalaluddin M, Li M, Hazell K, Bourquelot $\mathrm{P}$, Mateos $\mathrm{M}-\mathrm{V}$, Anderson K, Spencer A, Harousseau J-L, Blade J (2008) A phase II study of oral panobinostat (LBH589) in adult patients with advanced refractory multiple myeloma. ASH Annu Meet Abstr 112 (11):2774 EP -

188. Verheul HMW, Salumbides B, Van Erp K, Hammers H, Qian DZ, Sanni T, Atadja P, Pili R (2008) Combination strategy targeting the hypoxia inducible factor-1 alpha with mammalian target of rapamycin and histone deacetylase inhibitors. Clin Cancer Res 14 (11):3589-3597. doi:10.1158/1078-0432.CCR-07-4306

189. Altschuler SJ, Wu LF (2010) Cellular heterogeneity: do differences make a difference? Cell 141(4):559-563. doi:10.1016/j. cell.2010.04.033

190. Trumpp A, Wiestler OD (2008) Mechanisms of disease: cancer stem cells-targeting the evil twin. Nat Clin Prac Oncol 5(6):337347. doi: $10.1038 /$ ncponc 1110

191. Shackleton M (2010) Normal stem cells and cancer stem cells: similar and different. Semin Cancer Biol 20(2):85-92. doi:10.1016/j.semcancer.2010.04.002

192. Reya T, Morrison SJ, Clarke MF, Weissman IL (2001) Stem cells, cancer, and cancer stem cells. Nature 414(6859):105-111. doi: $10.1038 / 35102167$

193. Lin T, Jones RJ, Matsui W (2009) Cancer stem cells: relevance to SCT. Bone Marrow Transplant 43(7):517-523. doi:10.1038/ bmt.2009.19

194. Matsui W, Wang Q, Barber JP, Brennan S, Smith BD, Borrello I, McNiece I, Lin L, Ambinder RF, Peacock C, Watkins DN, Huff CA, Jones RJ (2008) Clonogenic multiple myeloma progenitors, stem cell properties, and drug resistance. Cancer Res 68(1):190 197. doi:10.1158/0008-5472.CAN-07-3096

195. Jones RJ, Matsui WH, Smith BD (2004) Cancer stem cells: are we missing the target? J Natl Cancer Inst 96(8):583-585

196. Peacock CD, Wang Q, Gesell GS, Corcoran-Schwartz IM, Jones E, Kim J, Devereux WL, Rhodes JT, Huff CA, Beachy PA, Watkins DN, Matsui W (2007) Hedgehog signaling maintains a tumor stem cell compartment in multiple myeloma. Proc Natl Acad Sci USA 104(10):4048-4053. doi:10.1073/pnas. 0611682104

197. Sharma SV, Lee DY, Li B, Quinlan MP, Takahashi F, Maheswaran S, Mcdermott U, Azizian N, Zou L, Fischbach MA, Wong K-K, Brandstetter K, Wittner B, Ramaswamy S, Classon M, Settleman J (2010) A chromatin-mediated reversible drug-tolerant state in cancer cell subpopulations. Cell 141(1):6980. doi:10.1016/j.cell.2010.02.027

198. Minucci S, Nervi C, Lo Coco F, Pelicci PG (2001) Histone deacetylases: a common molecular target for differentiation treatment of acute myeloid leukemias? Oncogene 20(24):3110 3115. doi:10.1038/sj.onc. 1204336

199. Grignani F, De Matteis S, Nervi C, Tomassoni L, Gelmetti V, Cioce M, Fanelli M, Ruthardt M, Ferrara FF, Zamir I, Seiser C, Grignani F, Lazar MA, Minucci S, Pelicci PG (1998) Fusion proteins of the retinoic acid receptor-alpha recruit histone deacetylase in promyelocytic leukaemia. Nature 391(6669):815-818. doi:10.1038/35901
200. Lin RJ, Nagy L, Inoue S, Shao W, Miller WH, Evans RM (1998) Role of the histone deacetylase complex in acute promyelocytic leukaemia. Nature 391(6669):811-814. doi:10. $1038 / 35895$

201. He LZ, Tolentino T, Grayson P, Zhong S, Warrell RP, Rifkind RA, Marks PA, Richon VM, Pandolfi PP (2001) Histone deacetylase inhibitors induce remission in transgenic models of therapy-resistant acute promyelocytic leukemia. J Clin Invest 108(9):1321-1330. doi:10.1172/JCI11537

202. Warrell RP, He LZ, Richon V, Calleja E, Pandolfi PP (1998) Therapeutic targeting of transcription in acute promyelocytic leukemia by use of an inhibitor of histone deacetylase. J Natl Cancer Inst 90(21):1621-1625

203. Zhou DC, Kim SH, Ding W, Schultz C, Warrell RP Jr, Gallagher RE (2002) Frequent mutations in the ligand-binding domain of PML-RARalpha after multiple relapses of acute promyelocytic leukemia: analysis for functional relationship to response to alltrans retinoic acid and histone deacetylase inhibitors in vitro and in vivo. Blood 99(4):1356-1363

204. Kitabayashi I, Yokoyama A, Shimizu K, Ohki M (1998) Interaction and functional cooperation of the leukemia-associated factors AML1 and p300 in myeloid cell differentiation. EMBO J 17 (11):2994-3004. doi:10.1093/emboj/17.11.2994

205. Wang J, Hoshino T, Redner RL, Kajigaya S, Liu JM (1998) ETO, fusion partner in $\mathrm{t}(8 ; 21)$ acute myeloid leukemia, represses transcription by interaction with the human $\mathrm{N}-\mathrm{CoR} / \mathrm{mSin} 3 /$ HDAC1 complex. Proc Natl Acad Sci USA 95(18):10860 10865

206. Fazi F, Zardo G, Gelmetti V, Travaglini L, Ciolfi A, Di Croce L, Rosa A, Bozzoni I, Grignani F, Lo-Coco F, Pelicci PG, Nervi C (2007) Heterochromatic gene repression of the retinoic acid pathway in acute myeloid leukemia. Blood 109(10):4432-4440. doi:10.1182/blood-2006-09-045781

207. Tabe Y, Jin L, Contractor R, Gold D, Ruvolo P, Radke S, Xu Y, Tsutusmi-Ishii Y, Miyake K, Miyake N, Kondo S, Ohsaka A, Nagaoka I, Andreeff M, Konopleva M (2007) Novel role of HDAC inhibitors in AML1/ETO AML cells: activation of apoptosis and phagocytosis through induction of annexin A1. Cell Death Differ 14(8):1443-1456. doi:10.1038/sj. cdd.4402139

208. Wang J, Saunthararajah Y, Redner RL, Liu JM (1999) Inhibitors of histone deacetylase relieve ETO-mediated repression and induce differentiation of AML1-ETO leukemia cells. Cancer Res 59(12):2766-2769

209. Odenike OM, Alkan S, Sher D, Godwin JE, Huo D, Brandt SJ, Green M, Xie J, Zhang Y, Vesole DH, Stiff P, Wright J, Larson RA, Stock W (2008) Histone deacetylase inhibitor romidepsin has differential activity in core binding factor acute myeloid leukemia. Clin Cancer Res 14(21):7095-7101. doi:10.1158/ 1078-0432.CCR-08-1007

210. Xia ZB, Anderson M, Diaz MO, Zeleznik-Le NJ (2003) MLL repression domain interacts with histone deacetylases, the polycomb group proteins HPC2 and BMI-1, and the corepressor C-terminal-binding protein. Proc Natl Acad Sci USA 100 (14):8342-8347. doi:10.1073/pnas.1436338100

211. Krivtsov AV, Armstrong SA (2007) MLL translocations, histone modifications and leukaemia stem-cell development. Nat Rev Cancer 7(11):823-833. doi:10.1038/nrc2253

212. Sobulo OM, Borrow J, Tomek R, Reshmi S, Harden A, Schlegelberger B, Housman D, Doggett NA, Rowley JD, Zeleznik-Le NJ (1997) MLL is fused to CBP, a histone acetyltransferase, in therapy-related acute myeloid leukemia with a $t$ (11;16)(q23;p13.3). Proc Natl Acad Sci USA 94(16):8732-8737

213. Thirman MJ, Gill HJ, Burnett RC, Mbangkollo D, McCabe NR, Kobayashi H, Ziemin-van der Poel S, Kaneko Y, Morgan $\mathrm{R}$, Sandberg AA et al (1993) Rearrangement of the MLL gene 
in acute lymphoblastic and acute myeloid leukemias with 11q23 chromosomal translocations. N Engl J Med 329(13):909-914

214. Slany RK (2009) The molecular biology of mixed lineage leukemia. Haematologica 94(7):984-993. doi:10.3324/haematol. 2008.002436

215. Liedtke M, Cleary ML (2009) Therapeutic targeting of MLL. Blood 113(24):6061-6068. doi:10.1182/blood-2008-12-197061

216. Tonelli R, Sartini R, Fronza R, Freccero F, Franzoni M, Dongiovanni D, Ballarini M, Ferrari S, D'Apolito M, Di Cola G, Capranico G, Khobta A, Campanini R, Paolucci P, Minucci S, Pession A (2006) G1 cell-cycle arrest and apoptosis by histone deacetylase inhibition in MLL-AF9 acute myeloid leukemia cells is p21 dependent and MLL-AF9 independent. Leukemia 20 (7):1307-1310. doi:10.1038/sj.leu.2404221
217. Burbury KL, Bishton MJ, Johnstone RW, Dickinson M, Szer J, Prince HM (2010) Sustained complete cytogenetic remission in MLL-aberrant leukemia following treatment with a Histone Deacetylase (HDAC) inhibitor (HDACi). Ann Hematol In Press. doi:10.1007/s00277-010-1099-6

218. Prince HM, Bishton MJ, Harrison SJ (2009) Clinical studies of histone deacetylase inhibitors. Clin Cancer Res 15(12):3958 3969. doi:10.1158/1078-0432.ccr-08-2785

219. Bots M, Johnstone RW (2009) Rational combinations using HDAC inhibitors. Clin Cancer Res 15(12):3970-3977. doi:10.1158/1078-0432.CCR-08-2786

220. Guardiola AR, Yao T-P (2002) Molecular cloning and characterization of a novel histone deacetylase HDAC10. J Biol Chem 277(5):3350-3356. doi:10.1074/jbc.M109861200 